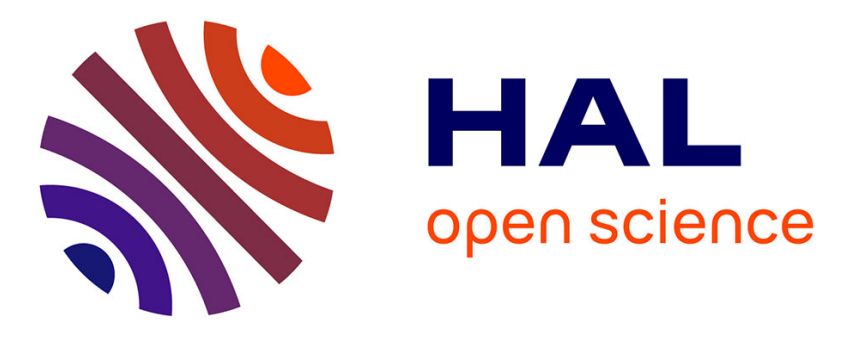

\title{
Ozone and carbon monoxide budgets over the Eastern Mediterranean
}

\author{
S. Myriokefalitakis, Nikolaos Daskalakis, G.S. Fanourgakis, A. Voulgarakis, \\ M.C. Krol, J.M.J. Aan de Brugh, M. Kanakidou
}

\section{- To cite this version:}

S. Myriokefalitakis, Nikolaos Daskalakis, G.S. Fanourgakis, A. Voulgarakis, M.C. Krol, et al.. Ozone and carbon monoxide budgets over the Eastern Mediterranean. Science of the Total Environment, 2016, 563-564, pp.40-52. 10.1016/j.scitotenv.2016.04.061 . insu-01330364

\section{HAL Id: insu-01330364 \\ https://hal-insu.archives-ouvertes.fr/insu-01330364}

Submitted on 4 Mar 2021

HAL is a multi-disciplinary open access archive for the deposit and dissemination of scientific research documents, whether they are published or not. The documents may come from teaching and research institutions in France or abroad, or from public or private research centers.
L'archive ouverte pluridisciplinaire HAL, est destinée au dépôt et à la diffusion de documents scientifiques de niveau recherche, publiés ou non, émanant des établissements d'enseignement et de recherche français ou étrangers, des laboratoires publics ou privés. 


\section{Ozone and carbon monoxide budgets over the Eastern 2 Mediterranean}

3 S. Myriokefalitakis ${ }^{a}$, N. Daskalakis ${ }^{\text {a,b,1, }}$, G. S. Fanourgakis ${ }^{\text {a }}$, A. Voulgarakis ${ }^{\text {c }}$, M. C. Krol 4 d,e,f , J. M. J. Aan de Brugh ${ }^{\text {f }}$ and M. Kanakidou ${ }^{\text {a }}$

$5{ }^{\text {a }}$ Environmental Chemical Processes Laboratory (ECPL), Department of Chemistry, University 6 of Crete, P.O. Box 2208, 70013 Heraklion, Greece

7 b Institute of Chemical Engineering, Foundation for Research and Technology Hellas 8 (FORTH/ICE - HT), 26504 Patras, Greece

$9{ }^{\mathrm{c}}$ Department of Physics, Imperial College London, London, UK

$10{ }^{\mathrm{d}}$ Meteorology and Air Quality Section, Wageningen University, Wageningen, The Netherlands

$11{ }^{\mathrm{e}}$ Institute for Marine and Atmospheric Research, Utrecht University, Utrecht, The Netherlands

$12{ }^{\mathrm{f}}$ SRON Netherlands Institute for Space Research, Utrecht, The Netherlands

13 'now at: LATMOS, Laboratoire Atmosphères, Milieux, Observations Spatiales, 14 UPMC/UVSQ/CNRS, Paris, France

16 Corresponding author: stelios@uoc.gr (S. Myriokefalitakis); mariak@uoc.gr (M. Kanakidou) 


\section{Abstract}

19 The importance of the long-range transport (LRT) on $\mathrm{O}_{3}$ and $\mathrm{CO}$ budgets over the Eastern

20 Mediterranean has been investigated using the state-of-the-art 3-dimensional global chemistry21 transport model TM4-ECPL. A 3-D budget analysis has been performed separating the Eastern 22 from the Western basins and the boundary layer (BL) from the free troposphere (FT). The FT of 23 the Eastern Mediterranean is shown to be a strong receptor of polluted air masses from the 24 Western Mediterranean, and the most important source of polluted air masses for the Eastern 25 Mediterranean $\mathrm{BL}$, with about $40 \%$ of $\mathrm{O}_{3}$ and of $\mathrm{CO}$ in the $\mathrm{BL}$ to be transported from the FT 26 aloft. Regional anthropogenic sources are found to have relatively small impact on regional air 27 quality in the area, contributing by about $8 \%$ and $18 \%$ to surface levels of $\mathrm{O}_{3}$ and $\mathrm{CO}$, 28 respectively. Projections using anthropogenic emissions for the year 2050 but neglecting climate 29 change calculate a surface $\mathrm{O}_{3}$ decrease of about $11 \%$ together with a surface $\mathrm{CO}$ increase of 30 roughly $10 \%$ in the Eastern Mediterranean.

31 Keywords: Ozone $\left(\mathrm{O}_{3}\right)$, Carbon monoxide $(\mathrm{CO})$, Eastern Mediterranean (EM), Long-range 32 transport (LRT), Free Troposphere (FT) 
35 Tropospheric $\mathrm{O}_{3}$ and $\mathrm{CO}$ are atmospheric pollutants both generated from natural and 36 anthropogenic sources depending on numerous physical and chemical processes (e.g. Lelieveld 37 and Dentener, 2000). They significantly affect the oxidizing capacity of the troposphere, climate (IPCC, 2013) and human and ecosystem's health (e.g. Jimoda, 2012; Ainsworth et al., 2012; Yue and Unger, 2014). Therefore, much attention is been paid to limit exceedances of threshold air pollution levels set by Environmental policy directives (e.g. DIRECTIVE 2008/50/EC Annex VII). Attribution of air pollution to sources is a prerequisite for designing measures to be taken to comply with such instructions. Pollution within urban agglomerations can build-up both locally (via local emissions and chemistry) and regionally (via transport from other regions) (e.g. Parrish et al., 2011). In the outflow of pollution centers, oxidation of volatile organic compounds (VOCs) and $\mathrm{CO}$ fosters the formation of secondary pollutants such as $\mathrm{O}_{3}$ (Molina and Molina, 2002), which is produced during the oxidation of VOCs in the presence of nitrogen oxides $\left(\mathrm{NO}_{\mathrm{x}}\right)$ (Crutzen, 1974; Derwent et al., 1996; Monks et al., 2009) following non-linear chemical processes. Therefore, it is particularly important to know whether actions on national level or coordinated actions on regional, or even global scale, are needed to limit air pollution in a region.

In this respect, Colette et al. (2012) analyzed atmospheric pollutant surface observations in Europe to derive trends over the past decade and compared them with multi-model chemistrytransport simulations. They found robust decreases of $\mathrm{NO}_{\mathrm{x}}$ throughout Europe except in SouthEastern France and North Italy and pointed out much larger model uncertainty over the Mediterranean than elsewhere. Over the Eastern Mediterranean (EM), they calculate a decrease in non-methane volatile organic compounds (NMVOC) to $\mathrm{NO}_{\mathrm{x}}$ ratio indicating a shift in the chemical regime in the area. Beekmann and Vautard (2010) have shown that the Mediterranean atmosphere is a $\mathrm{NO}_{\mathrm{x}}$ sensitive regime, while North-Western Europe is always VOC sensitive. Furthermore, modeling studies simulate high $\mathrm{O}_{3}$ concentrations in the summer, in agreement with the observed northern hemisphere summertime $\mathrm{O}_{3}$ maxima (Zanis et al., 2014). They also predict higher $\mathrm{O}_{3}$ levels in parts of the European continent as a result of a warmer climate in the near future (Langner et al., 2012; Zanis et al., 2014) and an increase in regional biogenic

62 emissions, both of which lead to a summertime regional $\mathrm{O}_{3}$ increase by $1 \mathrm{ppb}{ }^{\circ} \mathrm{C}^{-1}$ ( $\mathrm{Im}$ et al., 63 2011). Within large agglomerations of the $\mathrm{EM}, \mathrm{O}_{3}$ is significantly depressed through reaction 
64 with $\mathrm{NO}$, followed by $\mathrm{HNO}_{3}$ formation, in particular during wintertime (Im and Kanakidou, 65 2012).

66 The Mediterranean is among the most climatically sensitive regions of Europe, often exposed to 67 multiple stresses, such as simultaneous water shortage and air pollution exposure (IPCC, 2013).

68 It is also a characteristic region of a strongly coupled atmosphere-ocean system, composed by 69 two basins that differ in air circulation patterns (Millán et al., 2005; Kallos et al., 2007) - the 70 eastern and the western part. EM is affected by several large agglomerations, including the two 71 megacities (http://www.newgeography.com): Istanbul (13.6 M; Turkey) at the northeastern edge, Cairo (17.8 M; Egypt) at the southern edge of the basin, and one agglomeration, Athens, which gathers $40 \%(4 \mathrm{M})$ of Greece's total population. The rapid urbanization and the unique location of the EM as a cross-road of air masses affected by various pollution sources has turned air pollution into a challenging environmental problem in the area. Air masses from upwind locations carrying anthropogenic emissions, mainly from Europe, the Balkans and the Black Sea, meet with biomass burning (Sciare et al., 2008), biogenic (Liakakou et al., 2009) and other natural emissions (Gerasopoulos et al., 2011) from surrounding regions under sunny and warm conditions that enhance photochemical build-up of pollutants (Lelieveld et al., 2002; Kanakidou et al., 2011).

To quantify the impact of anthropogenic sources on air-quality of the region as the EM, the interand the intra- continental transport have to be considered and distinguished from the impact of the regional sources (HTAP, 2011). Such analysis remains challenging, due to the chemical complexity of atmospheric composition and the significant seasonal and interannual variability of meteorological conditions that affect transport patterns (e.g. driven by the North Atlantic 86 Oscillation; Pausata et al., 2012). Thus, large-scale chemistry-transport models (CTMs) are more appropriate tools for studying LRT (e.g. HTAP, 2011) than mesoscale models in which inter/intra-continental transport procedures are strongly driven by the imposed boundary conditions.

89 Satellite observations of tropospheric $\mathrm{O}_{3}, \mathrm{NO}_{2}$ and aerosol optical thickness (AOT) over the 90 Mediterranean clearly show the regional tropospheric $\mathrm{O}_{3}$ column maximum over the Mediterranean sea as well as the high $\mathrm{NO}_{2}$ columns in the urban pollution centers that surround 92 the basin (Kanakidou et al., 2011). Ground-based and satellite observations and numerical 93 modeling reviewed by Kanakidou et al. (2011) point out that air pollution transported to the area 94 is of similar importance to local sources for the background air pollution levels in the EM. 
95 Indeed, Drori et al. (2012) calculated that transport of air masses from Eastern Europe and 96 Turkey to the EM can contribute up to $50 \%$ of surface $\mathrm{CO}$ in the area. Gerasopoulos et al. 97 (2005) analyzing observations provided evidence that the main mechanism controlling the high 98 background tropospheric $\mathrm{O}_{3}$ levels in the EM is the long-range transport (LRT) from the 99 European continent (mainly during summer) and the local photochemical $\mathrm{O}_{3}$ build-up (especially 100 under western flow and stagnant wind conditions). In line with these findings, Zanis et al. (2014) 101 attributed the characteristic summertime tropospheric $\mathrm{O}_{3}$ pool over the $\mathrm{EM}$ to enhanced 102 downward transport from the upper troposphere and lower stratosphere that characterize the 103 summertime circulation over this region.

104 In the present study we investigate the contribution of LRT on $\mathrm{O}_{3}$ and $\mathrm{CO}$ budgets in the 105 Mediterranean basin, using a global CTM, the TM4-ECPL, to conduct a source attribution of 106 atmospheric composition changes. The relative impacts of regional anthropogenic, biomass 107 burning and natural emissions to the air quality in the EM are evaluated. First, the model set-up 108 and methodology followed are described. Then simulated $\mathrm{O}_{3}$ and $\mathrm{CO}$ levels are compared with 109 in-situ observations and satellite retrievals on a European and global level and model 110 deficiencies are discussed. The importance of regional emissions and the strength of LRT for air 111 quality are investigated based on sensitivity simulations and budget analysis. Projected changes

112 resulting from anthropogenic emissions scenarios for 2050 are also discussed.

\section{2. Materials and Methods}

\subsection{Global Model Set-up}

115 The global CTM TM4-ECPL (Daskalakis et al., 2015 and references therein) is able to simulate 116 oxidant chemistry, accounting for NMVOCs, as well as all major aerosol components, including 117 inorganic aerosols such as sulfate $\left(\mathrm{SO}_{4}{ }^{2-}\right)$, nitrate $\left(\mathrm{NO}_{3}{ }^{-}\right)$, ammonium $\left(\mathrm{NH}_{4}{ }^{+}\right)$using the 118 ISORROPIA II thermodynamic model (Fountoukis and Nenes, 2007) and secondary organic 119 aerosols (SOA). Compared to its parent TM4 model (van Noije et al., 2004), the present version 120 includes a description of glyoxal and other oxygenated organics (Myriokefalitakis et al., 2008) 121 and organic aerosols (Myriokefalitakis et al., 2010). The model also accounts for multiphase 122 chemistry in clouds and aerosol water that affects SOA formation (Myriokefalitakis et al., 2011) 123 and dust solubility (Myriokefalitakis et al., 2015). TM4-ECPL has been previously evaluated for 124 its ability i) to compute atmospheric composition and uncertainties associated with the use of 
125 different biomass burning emissions (Daskalakis et al., 2015), ii) to reproduce distributions of

126 tropospheric $\mathrm{O}_{3}$ and its precursors, as well as aerosols over Asia in summer 2008 as seen by 127 satellite and by in-situ observations (Quennehen et al., 2015), iii) to simulate the concentrations 128 of sulfate, black carbon (BC) and other aerosols in the Arctic (Eckhardt et al., 2015) and iv) to 129 evaluate the air quality impacts of short-lived pollutants based on current legislation for the 130 recent past and present (Stohl et al., 2015).

131 For the present study, year 2008 anthropogenic emissions of $\mathrm{NMVOC}, \mathrm{NO}_{\mathrm{x}}, \mathrm{CO}, \mathrm{SO}_{2}, \mathrm{NH}_{3}, \mathrm{OC}$ 132 and BC developed within the EU - FP7 ECLIPSE project (Stohl et al., 2015) have been used to 133 drive the chemistry in the model. Methane $\left(\mathrm{CH}_{4}\right)$ is calculated by nudging surface concentrations 134 to NOAA flask observations representative of the year of simulation (currently available for the 135 years 1989-2010; M. van Weele, personal communication, 2013). Since TM4-ECPL does not 136 explicitly calculate stratospheric chemistry, upper boundary conditions derived from climatology 137 records of stratospheric concentrations have been applied for $\mathrm{O}_{3}, \mathrm{CH}_{4}$ and $\mathrm{HNO}_{3}$. Thus, 138 stratospheric $\mathrm{O}_{3}$ concentrations are nudged above $50 \mathrm{hPa}$ to the concentrations of the year of 139 simulation based on the Multi-Sensor Reanalysis (MSR) climatology record, which is available 140 for the years 1978-2008 (van der A et al., 2010). For stratospheric $\mathrm{CH}_{4}$ concentrations, the 141 monthly climatology based on the HALogen Occultation Experiment (HALOE) on board the 142 Upper Atmosphere Research Satellite (UARS) (Grooß and Russell III, 2005) is applied above 50 $143 \mathrm{hPa}$. In the stratosphere, $\mathrm{HNO}_{3}$ is nudged at $10 \mathrm{hPa}$ using Sub-millimetre and Millimetre 144 Radiometer (SMR) observations from the Odin satellite (Brohede et al., 2008). This approach 145 enables a realistic representation of the concentrations of these compounds in the upper layers of 146 the model and thus of the vertical exchanges between the stratosphere and the troposphere. 147 Further detailed information on the model set up and the emission inventories used in the model 148 is available in Daskalakis et al. (2015).

149 Here, TM4-ECPL is driven by ECMWF (European Center for Medium - Range Weather 150 Forecasts) Interim re-analysis project (ERA-Interim) meteorology (Dee et al., 2011). Advection 151 of the tracers in the model is parameterized using the slopes scheme (Russell and Lerner, 1981). 152 Convective transport is parameterized based on the Tiedtke (1989) and Olivié (2004) scheme. 153 The vertical diffusion is parameterized as described in Louis (1979). The basic model 154 configuration used for this study (BASE simulation; see Table 1) has a horizontal resolution of $1553^{\circ}$ in longitude by $2^{\circ}$ in latitude, 34 vertical hybrid layers from the surface up to $0.1 \mathrm{hPa}$ and a 
156 time-step of $30 \mathrm{~min}$. For this work, all simulations were performed using meteorology for the

157 year 2008. A spin-up of one year (i.e. for the year 2007) with the respective meteorology and

158 emissions has been applied.

159

\subsection{Simulations and Emission Perturbations}

160 A number of simulations have been further performed for this study (Table 1) in order to 161 investigate the importance of LRT over the Mediterranean basin, focusing in particular on the

162 EM part. In short, simulations are performed to investigate the impact of regional anthropogenic 163 (MaskANTHRO), biogenic (MaskBIO) and biomass burning (MaskBB) emissions in the EM.

164 The simulation MaskALL neglects all regional emissions to provide information on the 165 background air-quality levels (sustained by mid - and long - range transport to the EM). Note 166 that for the present work, the area between $15^{\circ} \mathrm{E}-40^{\circ} \mathrm{E}$ in longitude and $30^{\circ} \mathrm{N}-45^{\circ} \mathrm{N}$ in latitude 167 is defined as the EM domain in the model (i.e. 25 longitudinal boxes and 15 latitudinal boxes for 168 the BASE simulation).

169 Additionally, simulations are performed to separately investigate the impact of LTR from non170 EM parts of Europe (MaskEU), North America (MaskNAM), Asia (MaskAS) and Africa 171 (MaskAF) to the EM background atmosphere. For this work, we use the HTAP phase 2 172 definitions (available online via the HTAP Wiki-page) for the source regions over which 173 emissions are masked. An additional simulation (FUTURE) investigates the impact of future 174 global anthropogenic emissions on $\mathrm{EM} \mathrm{O}_{3}$ levels, based on emission projections for the year 1752050 (Stohl et al., 2015). The sensitivity simulations for the investigation of emissions and LTR 176 strength are performed with the computationally cheaper, coarser horizontal resolution 177 configuration of the model (i.e. $6^{\circ}$ in longitude by $4^{\circ}$ in latitude).

\subsection{Global model evaluation methodology}

179 The model's performance has been evaluated by comparing the simulated $\mathrm{O}_{3}$ and $\mathrm{CO}$ levels with 180 surface observations, ozonesonde data and satellite retrievals, all for the year $2008 . \mathrm{O}_{3}$ surface 181 observations are taken from the European Monitoring Evaluation Program network (EMEP; 182 www.emep.int) and from the World Ozone and Ultraviolet Radiation Data Centre (WOUDC; 183 http://www.woudc.org) (the location of all surface observational sites used for model evaluation 184 is provided in the supplementary material Table S1 and Fig. S1). Ozonesonde data from sites 185 around the world provided by the WOUDC are used to evaluate the computed vertical structure 
186 of $\mathrm{O}_{3}$. $\mathrm{CO}$ surface observations around the globe for the year 2008 are taken from World Data

187 Centre for Greenhouse Gases (WDCGG; http://ds.data.jma.go.jp/gmd/wdcgg/).

188 TM4-ECPL results for tropospheric $\mathrm{O}_{3}$ and $\mathrm{CO}$ have been further compared with data from the 189 Tropospheric Emission Spectrometer (TES) satellite instrument. TES is a high resolution (0.1

$190 \mathrm{~cm}^{-1}$ ), infrared, Fourier Transform spectrometer aboard the NASA Aura satellite that follows a 191 polar Sun - synchronous orbit with an equator crossing time at 01:45 and 13:45 local time, and 192 has a repeating cycle of 16 days. The version 4 of TES global survey data, focusing on the FT 193 region of $800-400 \mathrm{hPa}$, are used here following the methods presented by Voulgarakis et al. 194 (2011). The TES products are provided in 67 levels in the vertical with a varying layer thickness 195 and with an averaged nadir footprint of $5 \mathrm{~km}$ by $8 \mathrm{~km}$ (Beer, 2006). Model 3-hourly output is 196 sampled at the times and locations of the TES measurements. The model values are 197 logarithmically interpolated onto the 67 TES pressure levels in the vertical, and the TES a priori 198 profiles and averaging kernels are applied. The processed observational and model data are 199 regridded to a $3^{\circ} \times 2^{\circ}$ grid (in longitude by latitude horizontal resolution).

200 To quantify the model's ability in simulating $\mathrm{O}_{3}$ and $\mathrm{CO}$ levels, statistical parameters commonly 201 used for model validation have been calculated: the correlation coefficient $(\mathrm{R})$, the standard error 202 (STD), the normalized mean bias (NMB), the normalized mean error (NME) and the root mean 203 square error (RMSE). In short, R reflects the strength of the linear relationship between model 204 results and observations (the ability of the model to simulate the observed variability), and it is 205 insensitive to either an additive or a multiplicative factor; STD is a numerical value indicating

206 the reliability of the mean, estimated by the sample standard deviation divided by the square root 207 of the sample size; MNE and MNB indicate the errors and biases towards overestimations; 208 RMSE is a measure of mean relative scatter reflecting both systematic and random errors. All 209 equations used for the statistical analysis of model results are provided in the supplementary 210 material (Eq. S1-S5).

\subsection{Budget Calculations}

212 To calculate the pollutant budget, the atmosphere has been divided into three vertical zones; the 213 boundary layer (BL; from the surface up to $850 \mathrm{hPa}$ - the 6 first levels of the model), the free 214 troposphere (FT; between $850 \mathrm{hPa}$ and the tropopause - the next 13 levels of the model) and the 215 stratosphere (ST; from the tropopause up to the top of the model's atmosphere $0.1 \mathrm{hPa}-$ the top 
21615 levels of the model). Pollutant lateral fluxes through the boundaries of the studied region have

217 been calculated for these three vertical zones as well as vertical exchange fluxes between the BL 218 and the FT and between the FT and the ST. Emissions, chemical production, chemical 219 destruction and deposition have also been computed for the budget analysis. The tropopause in 220 the model is here determined by the lowest grid boxes where monthly mean $\mathrm{O}_{3}$ concentrations 221 are greater than $150 \mathrm{ppb}_{\mathrm{v}}$ (i.e. the chemical tropopause as in Stevenson et al., 2006). The 222 chemical production of $\mathrm{O}_{3}$, which occurs through the oxidation of $\mathrm{CO}, \mathrm{CH}_{4}$, and NMVOCs in the 223 presence of $\mathrm{NO}_{x}$, is here computed as the sum of the change in $\mathrm{O}_{3}$ concentration due to chemistry 224 (net chemical production) and the $\mathrm{O}_{3}$ chemical loss computed as the sum of the reactions that 225 destroy $\mathrm{O}_{3}$. These are $\mathrm{O}_{3}$ photolysis followed by the reaction of the produced excited oxygen 226 atom with water vapour to form $\mathrm{OH}$ radical and $\mathrm{O}_{3}$ reactions with alkenes, hydrogen peroxy and 227 hydroxyl radicals (for the reactions see Myriokefalitakis et al., 2008). All budget terms are 228 calculated every model time step and averaged/integrated appropriately. Lifetimes are calculated 229 by dividing the burden with the respective loss budget term.

\section{3. Results and discussion}

231 Evaluation of the factors that control surface $\mathrm{O}_{3}$ and $\mathrm{CO}$ levels as reflected in atmospheric air 232 quality modeling is critical for air-quality strategies while an accurate simulation of vertical 233 profiles is important for $\mathrm{O}_{3}$ climate forcing calculations. In this respect, first the simulated 234 distributions of $\mathrm{O}_{3}$ and $\mathrm{CO}$ for the year 2008 are evaluated and then their budget over the

235 Mediterranean and the impact of specific sources to the surface air pollution levels are discussed.

\subsection{Evaluation of $\mathrm{O}_{3}$ and $\mathrm{CO}$ distributions}

\subsubsection{Evaluation of Surface $\mathrm{O}_{3}$}

238 To compare observations with model results, EMEP stations have been first divided into four 239 groups, representing different regions of Europe; namely: a) Northwestern Europe $\left(45^{\circ} \mathrm{N}-60^{\circ} \mathrm{N}\right.$; $\left.24010^{\circ} \mathrm{W}-15^{\circ} \mathrm{E}\right)$, b) Northeastern Europe $\left(45^{\circ} \mathrm{N}-60^{\circ} \mathrm{N} ; 15^{\circ} \mathrm{E}-40^{\circ} \mathrm{E}\right)$, c) Southwestern Europe $241\left(30^{\circ} \mathrm{N}-45^{\circ} \mathrm{N} ; 10^{\circ} \mathrm{W}-15^{\circ} \mathrm{E}\right)$ and d) Southeastern Europe $\left(30^{\circ} \mathrm{N}-45^{\circ} \mathrm{N} ; 15^{\circ} \mathrm{E}-40^{\circ} \mathrm{E}\right)$. Monthly

242 model results are interpolated for each station's coordinates and averaged separately for each 243 group to provide monthly mean surface concentrations of all stations for each of the 4 different 244 European domains (Fig. 1). Note that the number of stations varies between regions and that for 
245 each region the monthly observational data and the respective standard errors as well as model

246 calculations (for every station's coordinates) have been averaged appropriately.

247 Fig. 1a shows that for the Northwestern European domain, the model overestimates the available 248 observations in summer $(\mathrm{R}=0.8 ; \mathrm{MNB}=24 \%)$. The same pattern is simulated for the Northeastern 249 European domain (Fig. 1b; $\mathrm{R}=0.9 ; \mathrm{NMB}=27.2 \%$ ) where the model also overestimates observed $250 \mathrm{O}_{3}$ in summer. For both, the Southeastern and the Southwestern parts of Europe (Fig. 1d and Fig. 251 1c, respectively), TM4-ECPL satisfactory reproduces the observed variability of concentrations $252(\mathrm{R}=0.8)$ but with a general tendency to overestimate Southwestern Europe surface $\mathrm{O}_{3}$ in summer 253 (up to $60 \mathrm{ppb}_{\mathrm{v}}$ in summer, $\mathrm{NMB}=21.8 \%$, while much smaller overestimate is found for 254 Southeastern Europe; $\mathrm{NMB}=7.5 \%$ ). However, the general summertime model overestimation of 255 surface $\mathrm{O}_{3}$ compared to observations implies a potentially strong photochemical $\mathrm{O}_{3}$ production 256 calculated by the model, especially in the Western part of the Mediterranean, where the model 257 predicts $\mathrm{O}_{3}$ concentrations for the period from May to September that are higher than the 84.1 258 percentile $(+1 \sigma$, standard deviation) of the measurements (Fig. 1c). These discrepancies can be 259 attributed to the inaccuracies in emissions of $\mathrm{O}_{3}$ precursors and to the model's coarse resolution 260 that implies limited accuracy of non-linearities in chemistry (Kanakidou and Crutzen, 1999). 261 Another possible reason of the departure of $\mathrm{O}_{3}$ simulated concentrations from observations 262 during summer is the simulation of the dry deposition $\mathrm{O}_{3}$ flux.

263 Simulated surface $\mathrm{O}_{3}$ is further evaluated on a global scale against available surface observations 264 from the WOUDC, for the year 2008. Fig. S2a presents the point-by-point (scatter plot) of all available measurements from WOUDC and EMEP stations. Observed $\mathrm{O}_{3}$ mixing ratios are generally well reproduced by the model $\left(\mathrm{R}=0.7, \mathrm{RSME}=11.9 \mathrm{ppb}_{\mathrm{v}}\right)$, but the model in general tends to overestimate the observations $(\mathrm{MNB}=15.2 \%)$.

\subsubsection{Evaluation of $\mathrm{O}_{3}$ vertical structure}

269 Ozonesonde observations compiled by the WOUDC have also been used to evaluate the models' 270 capability in reproducing the $\mathrm{O}_{3}$ observed vertical profiles. Fig. 2 presents the comparison of 271 model results with observations in 2008 at the Hohenpeissenberg (Germany) and Payerne 272 (Switzerland) ozonesonde stations for five pressure levels (900 hPa, $800 \mathrm{hPa}, 500 \mathrm{hPa}, 400 \mathrm{hPa}$ 273 and $200 \mathrm{hPa}$ ), covering boundary layer and the low and high free troposphere. In order to 274 compare with the WOUDC observations, both the model results and the ozonesondes 
275

276

277

278

279

280

281

282

283

284

285

286

287

288

289

290

291

292

293

294

295

296

297

298

299

300

301

302

observations have been firstly linearly interpolated into layers of $50 \mathrm{hPa}$ from the surface to the top of the atmosphere. Comparisons for the other European stations available by WOUDC (i.e. Lindenber - Germany; Legiovo - Poland; De Bilt - The Netherlands; Ankara - Turkey) are further presented in the supplementary material (Fig. S3). The model captures the $\mathrm{O}_{3}$ distribution quite well almost at all sites throughout the lower troposphere. Differences in the model performance at the various stations can be due to the different characteristics of the stations, for instance the $\mathrm{O}_{3}$ precursor source regions, the intensity of photochemistry and the major transport patterns that are affecting them. Above $200 \mathrm{hPa}$ model overestimations are mainly attributed to the upper boundary conditions applied in the model (see Section 2.1). The point-by-point comparison of monthly mean values for all WOUDC ozonesonde tropospheric observations sites for the year 2008 (2344 pairs) is also presented in Fig. S2b. Globally, the model overestimates observations by roughly $20 \%(\mathrm{R}=0.8, \mathrm{NMB}=10.6 \%$, NME $20 \%)$. Similar performance is also found over Europe (Fig. S2b).

\subsubsection{Evaluation of Free Tropospheric $\mathrm{O}_{3}$ Concentrations}

Simulated $\mathrm{O}_{3}$ concentrations are further compared to the TES satellite retrievals for the middle/low FT. Fig. 3a depicts the annual mean calculated $\mathrm{O}_{3}$ concentrations between 800 and $400 \mathrm{hPa}$ (the vertical region with the maximum TES instrument sensitivity) over Europe calculated by TM4-ECPL and Fig. 3c shows the percentage difference from TES retrievals. The model tends to overestimate the mean free tropospheric $\mathrm{O}_{3}$ concentrations retrieved from TES observations over Northern Europe and Scandinavia (up to 3\%), while simulated $\mathrm{O}_{3}$ concentrations are underestimated up to $5 \%$ in the EM.

Fig. S4 also shows the seasonality in the zonal mean $\left(60^{\circ} \mathrm{S}-60^{\circ} \mathrm{N}\right) \mathrm{O}_{3}$ concentrations in the free troposphere $(800-400 \mathrm{hPa})$ as computed by the model and its difference from the TES observations. This comparison reveals an $\mathrm{O}_{3}$ overestimate by the model (up to about $10 \%$ ) in the northern high latitude regions during the summer months and an underestimate in lower latitudes that reaches $15 \%$ in the tropics during $\mathrm{NH}$ spring-summer. However, it is worth to note here that the disagreement between TM4-ECPL and TES could be partially explained by the observed TES positive bias between 3-10 ppbv (Nassar et al., 2008). 
304 TM4-ECPL results have also been compared with surface CO observations from the WDCGG

305

306

307

308

309

310

31

312

313

314

315

316

317

318

319

320

321

322

323

324

325

326

327

328

329

330

331

332

333

database for the year 2008. Fig. 4 presents the CO comparison of monthly mean model results with observations for countries within Europe; although the number of the $\mathrm{CO}$ monitoring stations is limited ( 8 stations for the year 2008 over Europe). For this comparison, monthly model results have been extracted for each station and an average for all stations in the same country has been obtained. Fig. 4 shows that the model satisfactory simulates the CO surface concentrations for Germany $(\mathrm{R}=0.7, \mathrm{NMB}=-4.9 \%)$, Slovenia $(\mathrm{R}=0.6, \mathrm{NMB}=-2.8 \%)$ and Switzerland ( $\mathrm{R}=0.6, \mathrm{NMB}=-3.3 \%$ ), while an offset is found for the station in The Netherlands $(\mathrm{R}=0.9, \mathrm{NMB}=-26.6 \%)$. The model evaluation for all $\mathrm{CO}$ surface observational sites over Europe and the globe for the year 2008 is also presented in Fig. S2c, based on monthly mean values. The point-by-point global comparison shows that the model generally underestimates the observations $(\mathrm{NMB}=-21 \%)$ but captures the variability $(\mathrm{R}=0.9)$.

\subsubsection{Evaluation of Free Tropospheric CO concentrations}

Simulated CO concentrations in the lower free troposphere are also compared with the TES products. Fig. $3 \mathrm{~b}$ depicts the annual mean CO concentrations between $800-400 \mathrm{hPa}$ over Europe calculated by TM4-ECPL and Fig. 3d shows the percentage difference between the model results and the CO TES product for 2008. The model underestimates the annual mean CO concentrations over Europe by about $10 \%$. The seasonality of the zonal mean CO concentrations between $60^{\circ} \mathrm{S}$ and $60^{\circ} \mathrm{N}$ in the middle/low free troposphere $(800-400 \mathrm{hPa})$ as calculated by TM4ECPL is presented in Fig. S4b. The model calculates a winter and a spring maximum in the Northern Hemisphere $(\mathrm{NH})$, and less than half concentrations in the Southern Hemisphere. Secondary maxima due to biomass burning processes are also simulated for the tropics from August to February. The model tends to underestimate $\mathrm{CO}$ summer concentrations in the NH . In the NH subtropics $\left(0^{\circ}-30^{\circ} \mathrm{N}\right)$ the model underestimation of $\mathrm{CO}$ concentrations reaches almost $20 \%$ from April to late June (Fig. S4d). On the contrary, the model tends to overestimate the retrieved CO tropospheric concentrations by about $10 \%$ in the mid-latitudes from September to December. Note however, that studies of TES CO products validation against aircraft data have shown a small bias of TES products that was slightly negative $(<10 \%)$ in mid-latitudes and slightly positive $(<10 \%$ ) in the tropics (Luo et al., 2007; Lopez et al., 2008). Thus, some TM4ECPL disagreement (Fig. S4f) can be attributed to observational errors. The tendency to 
334 underestimate northern extratropical $\mathrm{CO}$ and to overestimate tropical $\mathrm{CO}$ in the free troposphere

335 is, however, a common feature in current atmospheric modelling (e.g. Naik et al., 2013).

\subsection{Tropospheric budget analysis for $\mathrm{O}_{3}$ and $\mathrm{CO}$}

\section{3.2.1 Global troposphere}

338 Global tropospheric burden for $\mathrm{O}_{3}$ and $\mathrm{CO}$ governed by both sources (i.e., the chemical 339 production and the stratosphere-troposphere exchanges for $\mathrm{O}_{3}$, and emissions and chemical 340 production for $\mathrm{CO}$ ) and sinks (chemical destruction and deposition for both $\mathrm{O}_{3}$ and $\mathrm{CO}$ ) have 341 been calculated for the year 2008. Large $\mathrm{O}_{3}$ chemical production (5294 $\mathrm{Tg}^{-1}$ ) and chemical

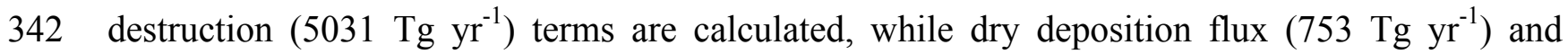
343 stratospheric net influx (490 $\mathrm{Tg}^{-1}$ ) are computed to be an order of magnitude lower. These 344 values are well in the range of the 26 model results that participated in the Stevenson et al. 345 (2006) model intercomparison study for the year 2000 (chemical production of $5110 \pm 606 \mathrm{Tg}$

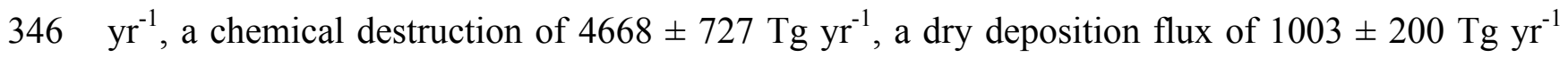
347 and a stratospheric influx of $552 \pm 200 \mathrm{Tg} \mathrm{yr}^{-1}$ ). Similarly, the mean tropospheric $\mathrm{O}_{3}$ burden of $348345 \mathrm{Tg}$ here calculated is close to the $344 \pm 39 \mathrm{Tg} \mathrm{O}_{3}$ tropospheric burden derived by Stevenson 349 et al. (2006).

350 For the year 2008 in the TM4-ECPL, global CO primary emissions amount $896 \mathrm{Tg} \mathrm{yr}^{-1}$, global $351 \mathrm{CO}$ chemical production is calculated to be $1946 \mathrm{Tg}^{-1}$ that is about twice the primary

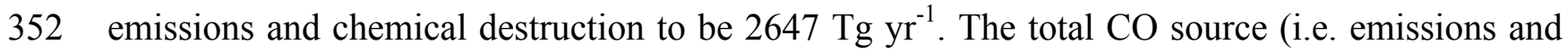
353 chemical production, $2427 \mathrm{Tg} \mathrm{yr}^{-1}$ for 2008) is in agreement with earlier studies; e.g. about 2760

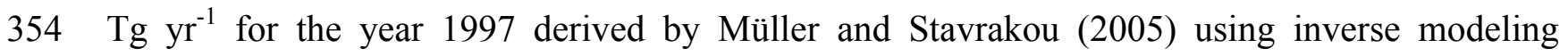
355 calculated the global CO source and $2455 \mathrm{Tg} \mathrm{yr}^{-1}$ calculated by Kanakidou and Crutzen (1999). 356 The chemical destruction of $\mathrm{CO}$ in the model is due to the oxidation by $\mathrm{OH}$ radicals. OH radical 357 oxidation is also the primary loss mechanism for methane $\left(\mathrm{CH}_{4}\right)$ and for this $\mathrm{OH}$ atmospheric 358 burden is commonly studied simultaneously to $\mathrm{CH}_{4}$ chemical lifetime. For the year 2008, the 359 TM4-ECPL calculates a tropospheric chemical lifetime of $\mathrm{CH}_{4}$ of about 8.1 years, which is close 360 to the low-end of mean tropospheric chemical $\mathrm{CH}_{4}$ lifetime due to $\mathrm{OH}$ oxidation for the year 361 2000, as derived from the ACCMIP (Atmospheric Chemistry and Climate Modeling 362 Intercomparison Project) multi-model mean (9.8 $\pm 1.6 \mathrm{yr}$; Voulgarakis et al., 2013). CO 363 tropospheric burden calculated by TM4-ECPL is $317 \mathrm{Tg}$ for the year 2008, similar to the 
364 estimate by Kanakidou and Crutzen (1999) and by 20\% lower than the $397 \mathrm{Tg}$ calculated by

365 Müller and Stavrakou (2005). However, the dry deposition sink calculated both by Bergamaschi

366 et al. (2000) (288 $\mathrm{Tg} \mathrm{yr}^{-1}$ ) and by Müller and Stavrakou (2005) (186-205 $\mathrm{Tg} \mathrm{yr}^{-1}$ ) is larger than

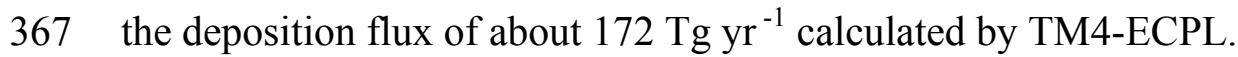

\section{3.2.2 Eastern Mediterranean}

369 Fig. 5 and Fig. 6 sketch the budget calculations over the Mediterranean, for $\mathrm{O}_{3}$ and for $\mathrm{CO}$ 370 respectively, separating also the Western from the Eastern basin (shaded/non - shaded areas) and 371 the BL (lower parts) from the FT (upper parts). For the BASE simulation, in the EM-BL $\mathrm{O}_{3}$ is

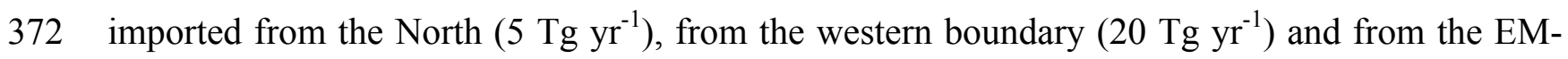
373 FT aloft (36 $\left.\mathrm{Tg} \mathrm{yr}^{-1}\right)$ and exported mainly to the South $\left(38 \mathrm{Tg} \mathrm{yr}^{-1}\right)$ and to the East $\left(24 \mathrm{Tg}^{-1}\right)$. 374 This result further indicates the significance of free tropospheric $\mathrm{O}_{3}$ intrusions for the $\mathrm{EM} \mathrm{O}_{3}$ 375 abundance in the BL. Photochemistry in the EM-BL (involving $\mathrm{NO}_{\mathrm{x}}$, VOCs photo-oxidation) 376 acts as an additional significant source for $\mathrm{O}_{3}$ in the region with a net chemical production 377 calculated to about $12 \mathrm{Tg} \mathrm{yr}^{-1}$. For $\mathrm{CO}$, the model calculates for the EM-BL a burden of 0.6 Tg of

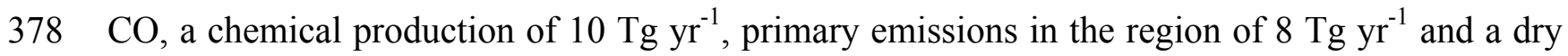

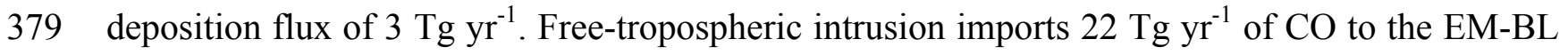
380 and $20 \mathrm{Tg} \mathrm{yr}^{-1}$ of $\mathrm{CO}$ are advected from the west. The model also calculates a strong CO outflow 381 of $32 \mathrm{Tg} \mathrm{yr}^{-1}$ to the South and a weaker import from the northern boundary that accounts about 6 $382{\mathrm{Tg} \mathrm{yr}^{-1}}^{-1}$

383 As far as it concerns the EM-FT (Fig. 5 and Fig. 6; upper parts), significant amounts of $\mathrm{O}_{3}$ and $384 \mathrm{CO}$ are advected through the western boundary (383 $\mathrm{Tg}^{-1}$ and $228 \mathrm{Tg} \mathrm{yr}^{-1}$, respectively) and 385 even larger amounts are exported due to chemical build-up and LRT to the East (445 $\mathrm{Tg} \mathrm{yr}^{-1}$ and $240 \mathrm{Tg} \mathrm{yr}^{-1}$, respectively). Three times higher $\mathrm{O}_{3}$ burden over the EM $(2.1 \mathrm{Tg})$ is simulated in the

387

388

389

390

391

392

393

394 FT than the $\mathrm{BL}$, while $\mathrm{O}_{3}$ residence time over the EM is calculated to be about 2.7 days in the BL and about 1.5 days in the FT. The model simulates a net $\mathrm{O}_{3}$ photochemical source of $3{\mathrm{Tg} \mathrm{yr}^{-1}}^{-1}$

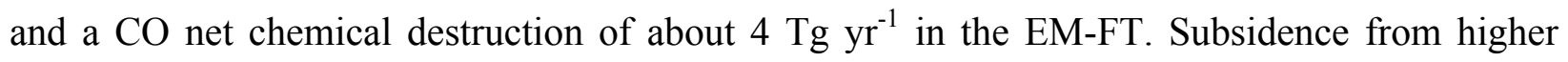
atmospheric layers is an important source for both $\mathrm{O}_{3}\left(48 \mathrm{Tg}_{\mathrm{yr}}^{-1}\right)$ and $\mathrm{CO}\left(12 \mathrm{Tg}^{-1}\right)$ in the EM-FT. Moreover, northern winds enriched in $\mathrm{O}_{3}$ and $\mathrm{CO}$ carry significant amounts of these

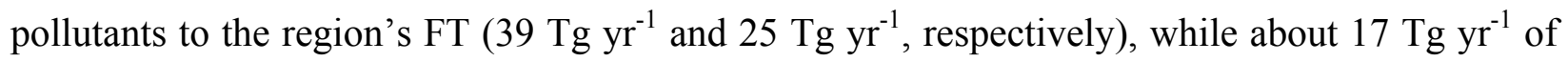
$\mathrm{O}_{3}$ are also imported from the southern boundary to the EM-FT, partly resulting from transport from Asia and Africa (17\% and 16\% respectively). 
396 Fig. 5 and Fig. 6 (shaded area) also depict $\mathrm{O}_{3}$ and $\mathrm{CO}$ budgets in the Western Mediterranean 397 (WM). TM4-ECPL calculates a significant influence from the surroundings since advection of 398 pollutants into the WM-FT (sum of all import terms) is about 2 orders of magnitude higher than the net photochemical source in this region.

400 The WM-BL is receiving 4 times lower amounts of $\mathrm{O}_{3}$ from the FT $\left(9 \mathrm{Tg} \mathrm{yr}^{-1}\right)$ than the Eastern 401 basin, and the chemical production of $\mathrm{O}_{3}\left(36 \mathrm{Tg}^{-1}{ }^{-1}\right)$ is slightly lower than that for EM. 402 According to TM4-ECPL model calculations, stratospheric $\mathrm{O}_{3}$ intrusions are an important source $403\left(75 \mathrm{Tg} \mathrm{yr}^{-1}\right)$ of tropospheric $\mathrm{O}_{3}$ over the entire Mediterranean. However, over the WM smaller $\mathrm{O}_{3}$ amounts are computed (roughly $36 \%$ of the total stratospheric intrusions), due to the stagnant conditions in the BL (Millán et al., 2005) as compared to the EM, even though an $\mathrm{O}_{3}$ burden of about $2.1 \mathrm{Tg}$ in the WM-FT is also calculated as for the case of EM-FT. In the WM-BL, the $\mathrm{O}_{3}$ chemical lifetime is calculated to be about 12.7 days while the overall residence time in the western basin is estimated at about 4.7 days (i.e. about 33\% longer than that in the EM) due to deposition and fast outflow. Ventilation by advection is about 3 times faster in the EM than in the WM (about 4 days versus 12 days, respectively). However, the chemical lifetime of $\mathrm{O}_{3}$ in the BL is almost identical in the two basins (about 12 days) while the subsidence from the FT is

412 about 4 times higher in the EM than in the WM. Overall, the EM-BL is acting as a receptor of $\mathrm{O}_{3}$ 413 of air masses mainly from the FT (59\%) and the WM (33\%), as well as a source of $\mathrm{O}_{3}$ and CO 414 for the downwind locations to the South (60\%) and the East (40\%). Air-masses advected from 415 the North are about 2 times richer in $\mathrm{O}_{3}$ in the WM-FT than in the EM-FT, even though the 416 subsidence from the stratosphere provides about $78 \%$ more $\mathrm{O}_{3}$ in the EM-FT than in the WM417 FT.

\subsection{Contribution of sources to air pollution}

419 TM4-ECPL calculations show that the Mediterranean (Fig. 7c) is among the regions 420 experiencing the highest surface $\mathrm{O}_{3}$ concentrations in the globe together with eastern U.S. and 421 Central Asia (Fig. 7a). In general, TM4-ECPL calculates high surface $\mathrm{O}_{3}$ concentrations in the 422 mid-latitudes of the NH, over regions with high anthropogenic activity (US, Europe and China) 423 as well as in the tropical areas affected by biomass burning emissions (Fig. 7a). The zonal mean 424 distribution of $\mathrm{O}_{3}$ concentrations (not shown) presents enhanced values in the sub-tropics 
425 because of $\mathrm{O}_{3}$ production in regions affected by biomass burning such as Central Africa. The 426 model also calculates high $\mathrm{O}_{3}$ concentrations in the pollution plumes over the Atlantic and the 427 outflow over Japan.

428 Simulated surface CO also shows enhanced concentrations over polluted regions of the NH (i.e. 429 US, Europe and China) as well as the biomass burning peaks over Central Africa and the 430 Amazon Basin (Fig. 7b). Although, primary CO sources are mainly from anthropogenic origin 431 (roughly 60\%), CO secondary sources from VOC oxidation are calculated to be by $70 \%$ from $432 \mathrm{CH}_{4}$ and by $30 \%$ from NMVOCs (e.g. Poisson et al., 2000). The CO zonal mean distribution (not 433 shown) clearly shows the high $\mathrm{NH}$ concentrations, resulting from both high primary and 434 secondary sources north of $30^{\circ} \mathrm{S}$. TM4-ECPL calculates higher CO concentrations in the winter 435 (not shown) mainly due to the lower loss by reaction with $\mathrm{OH}$ that presents a seasonal wintertime 436 minimum in the troposphere (reduced oxidizing capacity).

437 In order to investigate the contribution of local and distant sources to air pollution in the BL, 438 emission perturbation simulations have been performed and compared to the base case 439 simulation (BASE) as previously explained in Section 2.2. Percent differences were calculated as $440100 *(B A S E-M a s k X) / B A S E$; where MaskX is the respective sensitivity simulation as presented 441 in Table 1.

\section{$442 \quad 3.3 .1 \mathrm{O}_{3}$ surface concentrations}

443 The model (BASE) calculates a surface annual $\mathrm{O}_{3}$ mean mixing ratio of about $43 \mathrm{ppb}_{\mathrm{v}}$ over the 444 European domain in the model (Fig. 7c), with a maximum exceeding $55 \mathrm{ppb}_{\mathrm{v}}$ over the central 445 and Eastern Mediterranean. The calculations attribute up to $15 \%$ of the $\mathrm{O}_{3}$ surface concentrations 446 to the regional anthropogenic emissions in the EM (MaskAnthro vs. BASE), with an annual 447 mean contribution in the EM of about 8\% (Fig. 8a). Additionally, up to 5\% on an annual basis is 448 associated with biogenic emissions (MaskBIO vs. BASE), but less than 1\% is due to biomass 449 burning emissions (MaskBB vs. BASE). All regional emissions accounted by the model 450 (MaskALL vs. BASE) are responsible for about 11\% of $\mathrm{O}_{3}$ surface levels on annual base, with a 451 maximum contribution of $18 \%$ over and south of the Levantine Sea (Fig. 8c), indicating thus the 452 importance of air-mass transport from neighboring regions (i.e. LRT by advection and 453 subsidence to the region). When European emissions are neglected (MaskEU vs. BASE), the 454 model calculates about $13 \%$ of reduction in $\mathrm{O}_{3}$ surface concentrations over the EM (Fig. S5a). 
455 Northern America's emissions (Fig. S5b) affect the surface $\mathrm{O}_{3}$ concentrations over the entire 456 European continent by about 5\% (MaskNAM vs. BASE). Asian emissions (MaskAS vs. BASE) 457 affect $\mathrm{O}_{3}$ surface concentrations by $10 \%$ on annual basis (Fig. S5c), while the African continent's 458 emissions (MaskAF vs. BASE) contribute about 4\% to EM basin surface $\mathrm{O}_{3}$ concentrations (Fig. 459 S5d).

\subsubsection{CO surface concentrations}

461 For $\mathrm{CO}$ concentrations over Europe, the model calculates a surface annual mean mixing ratio of $462110 \mathrm{ppb}_{\mathrm{v}}$, with a maximum concentration of $128 \mathrm{ppb}_{\mathrm{v}}$ over EM (Fig. 7d). Anthropogenic local 463 emissions in the EM contribute by $18 \%$ to the surface CO levels in the EM (Fig. 8b) annually. 464 Maximum anthropogenic contribution (roughly 32\%) to surface CO concentrations is calculated 465 over Cairo. On the other hand, CO concentrations over the EM are associated by about 9\% on 466 annual basis with regional biogenic VOC oxidation (not shown) and about 3\% are due to 467 biomass burning emissions (not shown). All regional emissions accounted by the model (Fig. 8d) 468 are responsible for $23 \%$ of CO surface levels, while the remaining could be attributed to LRT. 469 On an annual basis, European emissions (MaskEU) contribute by about 25\% to the calculated 470 CO surface concentrations over the EM (Fig. S6a), Northern America's emissions (MaskNAM)

471 by $12 \%$ (Fig. S6b), Asian emissions (MaskAS) by 26\% (Fig. S6c) and African emissions 472 (MaskAF) by 11\% (Fig. S6d).

\subsection{Projected changes due to anthropogenic emissions}

474 In Fig. 8e and 8f, the simulation using anthropogenic emissions as projected for the year 2050 475 (FUTURE) is compared to the BASE (i.e. 100x(FUTURE-BASE)/BASE ). A 16\% increase in 476 surface $\mathrm{O}_{3}$ over central Europe is due to the reduction in $\mathrm{NO}_{\mathrm{x}}$ anthropogenic emissions (a 477 reduction in the $\mathrm{NO}_{x} \mathrm{O}_{3}$-titration effect), while a decrease in surface $\mathrm{O}_{3}$ by about $11 \%$ is 478 calculated for the Mediterranean (Fig. 8e) is due to the reduction in $\mathrm{O}_{3}$ chemical formation and to 479 import/export fluxes changes. On the opposite, $\mathrm{CO}$ surface concentrations are calculated to 480 decrease by about $10 \%$ over central Europe. This change is the overall effect of the decrease 481 (more than 40\%) in the primary anthropogenic emissions, an almost similar in magnitude 482 increase in the $\mathrm{OH}$ radical concentrations (affecting both the secondary $\mathrm{CO}$ source and the 483 chemical sink of $\mathrm{CO}$ ) and changes in the transport fluxes. The opposite trend is projected for the 484 EM, where an increase (Fig. 8f) by about $10 \%$ in CO surface concentrations is computed. This 
485 change reflects mainly the increase of $\mathrm{CO}$ primary anthropogenic emissions in the south 486 combined with a reduction in surface $\mathrm{OH}$ levels by about $20 \%$ (e.g. due to smaller precursor $\mathrm{O}_{3}$ 487 concentrations) that leads to a reduction in both the secondary source and in the chemical sink of $488 \mathrm{CO}$ in the EM.

489

490

491

492

493

495

496

498

499

500

501

502

503

504

505

506

507

508

509

510

511

512

513

514

515

All FUTURE $\mathrm{O}_{3}$ imports compared to the BASE simulation (computed as [100x(FUTUREBASE)/BASE]) due to advection to EM-BL are calculated to decrease roughly by $13 \%$ on average, with the Northern boundaries imports to decrease, however, by about $17 \%$. On the other hand, exports from the EM-BL are also calculated to decrease under 2050 anthropogenic emissions, mainly to the South (14\%). Note that the same decrease is also calculated for the EMFT, resulting thus to a decrease in downdraft to EM-BL of about 13\%. As far as it concerns the $\mathrm{CO}$, in the EM-BL increases in CO imports from the EM-FT boundary and from the West (about $24 \%$ and $17 \%$, respectively) are calculated. In contrast, a decrease in import from the North of about $14 \%$ is also calculated for EM-BL, which can also be attributed to impact of Asian emissions as discussed in the previous section (Section 3.3.2). $\mathrm{CO}$ has a longer lifetime compared to $\mathrm{O}_{3}$, which makes the LRT Asian contribution to European pollution more pronounced on $\mathrm{CO}$ than on $\mathrm{O}_{3}$ within Europe (i.e. Fig. S6c). For the FUTURE simulation, both meteorology and $\mathrm{CH}_{4}$ concentrations are kept constant in the model, thus the increase in $\mathrm{CO}$ chemical production and destruction is attributed to the respective increase in $\mathrm{O}_{3}$ levels and thus in $\mathrm{OH}$ production, leading to a more aggressive $\mathrm{CO}$ loss. As explained in section 2.1 changes in meteorology and the stratospheric boundary conditions, which may occur in the future under climate change, are not taken into account by the model. Thus, the computed anti-correlation between $\mathrm{O}_{3}$ and $\mathrm{CO}$ future changes over the EM is driven by the changes in anthropogenic emissions and the induced differences in the oxidation capacity.

\section{Conclusions}

The global chemistry-transport model TM4-ECPL is able to reproduce observations of $\mathrm{O}_{3}$ and $\mathrm{CO}$ at the surface, the BL and in FT in the rural and remote atmosphere over Europe. This allowed us to analyze the $\mathrm{O}_{3}$ and $\mathrm{CO}$ budget over the EM. We found that the EM atmosphere is strongly affected by air masses from surrounding regions and thus by sources other than local. Similar conclusions for the EM, documented in different ways, have been reached by other modeling studies (e.g. Im and Kanakidou, 2012; Zanis et al., 2014) as well as in the reviews by Kanakidou et al. (2011) and Kallos et al. (2013) and references therein. In the present study we 
516 further quantified the contribution of various sources to the $\mathrm{O}_{3}$ and $\mathrm{CO}$ budget in the EM. In

517 particular, our calculations show that local anthropogenic emissions are responsible for about 8\%

518 of surface $\mathrm{O}_{3}$ concentration and $18 \%$ of $\mathrm{CO}$ surface concentrations, while downward transport

519 from the FT provides about $38 \%$ of $\mathrm{O}_{3}$ sources and about $33 \%$ of $\mathrm{CO}$ sources into the EM-BL

520 and horizontal advection from the surrounding regions contributes by about $51 \%$ and $27 \%$,

521 respectively. Therefore, neglecting all the emissions in the EM region (i.e. anthropogenic,

522 biomass burning, biogenic and natural emissions) leads to a reduction in annual mean surface

523 concentrations of only $11 \%$ in $\mathrm{O}_{3}$ and of $23 \%$ in $\mathrm{CO}$.

524 For anthropogenic emissions projected for the year 2050, the model calculates a reduction of 525 about $11 \%$ in the regional $\mathrm{O}_{3}$ surface concentrations, with a contemporaneous increase in $\mathrm{CO}$ 526 surface concentrations of roughly $10 \%$ in the EM. The opposite changes of $\mathrm{O}_{3}$ and $\mathrm{CO}$ due to 527 future anthropogenic emissions could be attributed to the respective changes of oxidation 528 capacity within the EM and to changes in the fluxes in and out the EM which are driven by 529 large-scale concentration changes. However, our calculations do not account for potential 530 changes in meteorology and stratospheric boundary conditions. Overall, this work indicates that $531 \mathrm{O}_{3}$ and $\mathrm{CO}$ surface levels in the EM are mainly driven by LRT of pollution and related 532 precursors within the BL, but also through the FT and subsequent downdraft to the BL. This 533 implies that mitigation of local anthropogenic emissions is not sufficient for significant 534 improvements in air quality in the Mediterranean region, and that coordinated efforts between 535 the countries surrounding and located upwind of the basin are required.

536 
538 This work has been initiated in the frame of the CityZEN project (megaCITY - Zoom for the 539 Environment, FP7-ENV-2008-212095) and has been finalized with support to SM and GSF by 540 ECLIPSE (Evaluating the CLimate and Air Quality ImPacts of Short-livEd Pollutants, FP7541 ENV-2011-282688) and to ND by PEGASOS (Pan - European Gas - AeroSOls - climate 542 interaction Study, FP7-ENV-2010-265148) collaborative projects funded by the European 543 Commission. We thank Prof. N. Mihalopoulos and Dr. G. Kouvarakis for Finokalia station data 544 availability and the World Ozone and Ultraviolet Radiation Data Centre (WOUDC) for 545 ozonesondes data availability. 
Ainsworth, E.A., Yendrek, C.R., Sitch, S., Collins, W.J., Emberson, L.D., 2012. The effects of tropospheric ozone on net primary productivity and implications for climate change. Annu. Rev. Plant Biol. 63, 637-61. doi:10.1146/annurev-arplant-042110-103829

Beekmann, M., Vautard, R., 2010. A modelling study of photochemical regimes over Europe: Robustness and variability. Atmos. Chem. Phys. 10, 10067-10084. doi:10.5194/acp-10$10067-2010$

Beer, R., 2006. TES on the aura mission: scientific objectives, measurements, and analysis overview. IEEE Trans. Geosci. Remote Sens. 44, 1102-1105. doi:10.1109/TGRS.2005.863716

Bergamaschi, P., Hein, R., Heimann, M., Crutzen, P.J., 2000. Inverse modeling of the global CO cycle: 1. Inversion of CO mixing ratios. J. Geophys. Res. 105, 1909. doi: $10.1029 / 1999 j \mathrm{j} 900818$

Brohede, S., McLinden, C.A., Urban, J., Haley, C.S., Jonsson, A.I., Murtagh, D., 2008. Odin stratospheric proxy $\mathrm{NO}_{\mathrm{y}}$ measurements and climatology. Atmos. Chem. Phys. 8, 57315754. doi:10.5194/acp-8-5731-2008

Colette, A., Granier, C., Hodnebrog, Ø., Jakobs, H., Maurizi, A., Nyiri, A., Rao, S., Amann, M., Bessagnet, B., D'Angiola, A., Gauss, M., Heyes, C., Klimont, Z., Meleux, F., Memmesheimer, M., Mieville, A., Rouil, L., Russo, F., Schucht, S., Simpson, D., Stordal, F., Tampieri, F., Vrac, M., 2012. Future air quality in Europe: a multi-model assessment of projected exposure to ozone. Atmos. Chem. Phys. 12, 10613-10630. doi:10.5194/acp-1210613-2012

Crutzen, P.J., 1974. Photochemical reactions initiated by and influencing ozone in unpolluted tropospheric air. Tellus 26, 47-57. doi:10.1111/j.2153-3490.1974.tb01951.x

Daskalakis, N., Myriokefalitakis, S., Kanakidou, M., 2015. Sensitivity of tropospheric loads and lifetimes of short lived. Atmos. Chem. Phys. 15, 3543-3563. doi:10.5194/acp-15-35432015

Dee, D.P., Uppala, S.M., Simmons, A.J., Berrisford, P., Poli, P., Kobayashi, S., Andrae, U., Balmaseda, M.A., Balsamo, G., Bauer, P., Bechtold, P., Beljaars, A.C.M., van de Berg, L., Bidlot, J., Bormann, N., Delsol, C., Dragani, R., Fuentes, M., Geer, A.J., Haimberger, L., Healy, S.B., Hersbach, H., Hólm, E. V, Isaksen, L., Kållberg, P., Köhler, M., Matricardi, M., McNally, A.P., Monge-Sanz, B.M., Morcrette, J.J., Park, B.K., Peubey, C., de Rosnay, P., Tavolato, C., Thépaut, J.N., Vitart, F., 2011. The ERA-Interim reanalysis: configuration and performance of the data assimilation system. Q. J. Roy. Meteor. Soc. 137, 553-597. doi:10.1002/qj. 828

Derwent, R.G., Jenkin, M.E., Saunders, S.M., 1996. Photochemical ozone creation potentials for a large number of reactive hydrocarbons under European conditions. Atmos. Environ. 30, 181-199. doi:10.1016/1352-2310(95)00303-G

Drori, R., Dayan, U., Edwards, D.P., Emmons, L.K., Erlick, C., 2012. Attributing and quantifying carbon monoxide sources affecting the Eastern Mediterranean: a combined satellite, modelling, and synoptic analysis study. Atmos. Chem. Phys. 12, 1067-1082. doi:10.5194/acp-12-1067-2012

Eckhardt, S., Quennehen, B., Olivié, D.J.L., Berntsen, T.K., Cherian, R., Christensen, J.H., 
603

604

605

606

607

608

609

610

611

612

613

614

615

616

617

618

619

620

621

622

623

624

625

626

627

628

629

630

631

632

Collins, W., Crepinsek, S., Daskalakis, N., Flanner, M., Herber, A., Heyes, C., Hodnebrog, Ø., Huang, L., Kanakidou, M., Klimont, Z., Langner, J., Law, K.S., Lund, M.T., Mahmood, R., Massling, A., Myriokefalitakis, S., Nielsen, I.E., Nøjgaard, J.K., Quaas, J., Quinn, P.K., Raut, J.-C., Rumbold, S.T., Schulz, M., Sharma, S., Skeie, R.B., Skov, H., Uttal, T., Salzen, K. von, Stohl, A., 2015. Current model capabilities for simulating black carbon and sulfate concentrations in the Arctic atmosphere: a multi-model evaluation using a comprehensive measurement data set. Atmos. Chem. Phys. 15, 9413-9433. doi:doi:10.5194/acp-15-94132015

Fountoukis, C., Nenes, A., 2007. ISORROPIA II: a computationally efficient thermodynamic equilibrium model for $\mathrm{K}+-\mathrm{Ca} 2+-\mathrm{Mg} 2+-\mathrm{NH} 4+-\mathrm{Na}+-\mathrm{SO} 42-$ - NO3- - $\mathrm{Cl}-$ - $\mathrm{H} 2 \mathrm{O}$ aerosols. Atmos. Chem. Phys. 7, 4639-4659. doi:10.5194/acp-7-4639-2007

Gerasopoulos, E., Amiridis, V., Kazadzis, S., Kokkalis, P., Eleftheratos, K., Andreae, M.O., Andreae, T.W., El-Askary, H., Zerefos, C.S., 2011. Three-year ground based measurements of aerosol optical depth over the Eastern Mediterranean: the urban environment of Athens. Atmos. Chem. Phys. 11, 2145-2159. doi:10.5194/acp-11-2145-2011

Gerasopoulos, E., Kouvarakis, G., Vrekoussis, M., Kanakidou, M., Mihalopoulos, N., 2005. Ozone variability in the marine boundary layer of the eastern Mediterranean based on 7year observations. J. Geophys. Res. D Atmos. 110, 1-12. doi:10.1029/2005JD005991

Grooß, J.U., Russell III, J.M., 2005. Technical note: A stratospheric climatology for O3, H2O, $\mathrm{CH} 4, \mathrm{NOx}, \mathrm{HCl}$ and $\mathrm{HF}$ derived from HALOE measurements. Atmos. Chem. Phys. 5, 2797-2807. doi:10.5194/acp-5-2797-2005

HTAP, T., 2011. Hemispheric Transport of Air Pollution 2010 Part A: Ozone And Particulate Matter. Air Pollut. Stud.

Im, U., Kanakidou, M., 2012. Impacts of East Mediterranean megacity emissions on air quality. Atmos. Chem. Phys. 12, 6335-6355. doi:10.5194/acp-12-6335-2012

Im, U., Markakis, K., Poupkou, A., Melas, D., Unal, A., Gerasopoulos, E., Daskalakis, N., Kindap, T., Kanakidou, M., 2011. The impact of temperature changes on summer time ozone and its precursors in the Eastern Mediterranean. Atmos. Chem. Phys. 11, 3847-3864. doi:10.5194/acp-11-3847-2011

Jimoda, L., 2012. Effects of particulate matter on human health, the ecosystem, climate and materials: A review. Facta Univ. Work. Living ... 9, 27-44.

Kallos, G., Astitha, M., Katsafados, P., Spyrou, C., 2007. Long-Range Transport of Anthropogenically and Naturally Produced Particulate Matter in the Mediterranean and North Atlantic: Current State of Knowledge. J. Appl. Meteorol. Climatol. 46, 1230-1251. doi:10.1175/JAM2530.1

Kallos, G., Mitsakou, C., Alastuey, A., van Aardenne, J., Astitha, M., Cusack, M., Doering, U., Gerasopoulos, E., Hatzianastassiou, N., Kanakidou, M., Kushta, J., Lelieveld, J., Levin, Z., Mihalopoulos, N., Millán, M., Palau, J.L., Perez, N., Pey, J., Querol, X., Solomos, S., Spyrou, C., Theodosi, C., Zerefos, C., 2013. Mechanisms of Climate Variability, Air Quality and Impacts of Atmospheric Constituents in the Mediterranean Region, in: Navarra, A., Tubiana, L. (Eds.), Advances in Global Change Research. Springer Netherlands, Dordrecht, pp. 119-156. doi:10.1007/978-94-007-5781-3_4

Kanakidou, M., Crutzen, P.J., 1999. The photochemical source of carbon monoxide: Importance, 
642

643

644

645

646

647

648

649

650

651

652

653

654

655

656

657

658

659

660

661

662

663

664

665

666

667

668

669

670

671

672

673

674

675

uncertainties and feedbacks. Chemosph. - Glob. Chang. Sci. 1, 91-109. doi:http://dx.doi.org/10.1016/S1465-9972(99)00022-7

Kanakidou, M., Mihalopoulos, N., Kindap, T., Im, U., Vrekoussis, M., Gerasopoulos, E., Dermitzaki, E., Unal, A., Koçak, M., Markakis, K., Melas, D., Kouvarakis, G., Youssef, A.F., Richter, A., Hatzianastassiou, N., Hilboll, A., Ebojie, F., Wittrock, F., von Savigny, C., Burrows, J.P., Ladstaetter-Weissenmayer, A., Moubasher, H., 2011. Megacities as hot spots of air pollution in the East Mediterranean. Atmos. Environ. 45, 1223-1235. doi:10.1016/j.atmosenv.2010.11.048

Kanakidou, M., Singh, H.B., Valentin, K.M., Crutzen, P.J., 1991. A two-dimensional study of ethane and propane oxidation in the troposphere. J. Geophys. Res. 96, 15395-15413. doi: $10.1029 / 91 \mathrm{jd} 01345$

Langner, J., Engardt, M., Baklanov, A., Christensen, J.H., Gauss, M., Geels, C., Hedegaard, G.B., Nuterman, R., Simpson, D., Soares, J., Sofiev, M., Wind, P., Zakey, A., 2012. A multi-model study of impacts of climate change on surface ozone in Europe. Atmos. Chem. Phys. 12, 10423-10440. doi:10.5194/acp-12-10423-2012

Lelieveld, J., Berresheim, H., Borrmann, S., Crutzen, P.J., Dentener, F.J., Fischer, H., Feichter, J., Flatau, P.J., Heland, J., Holzinger, R., Korrmann, R., Lawrence, M.G., Levin, Z., Markowicz, K.M., Mihalopoulos, N., Minikin, A., Ramanathan, V., De Reus, M., Roelofs, G.J., Scheeren, H. a, Sciare, J., Schlager, H., Schultz, M., Siegmund, P., Steil, B., Stephanou, E.G., Stier, P., Traub, M., Warneke, C., Williams, J., Ziereis, H., 2002. Global air pollution crossroads over the Mediterranean. Science 298, 794-9. doi:10.1126/science. 1075457

Lelieveld, J., Dentener, F.J., 2000. What controls tropospheric ozone? J. Geophys. Res. 105, 3531. doi:10.1029/1999JD901011

Liakakou, E., Bonsang, B., Williams, J., Kalivitis, N., Kanakidou, M., Mihalopoulos, N., 2009. C2-C8 NMHCs over the Eastern Mediterranean: Seasonal variation and impact on regional oxidation chemistry. Atmos. Environ. 43, 5611-5621. doi:10.1016/j.atmosenv.2009.07.067

Lopez, J.P., Luo, M., Christensen, L.E., Loewenstein, M., Jost, H., Webster, C.R., Osterman, G., 2008. TES carbon monoxide validation during two AVE campaigns using the Argus and ALIAS instruments on NASA's WB-57F. J. Geophys. Res. 113, D16S47. doi:10.1029/2007JD008811

Louis, J.-F., 1979. A parametric model of vertical eddy fluxes in the atmosphere. BoundaryLayer Meteorol. 17, 187-202. doi:10.1007/BF00117978

Luo, M., Rinsland, C., Fisher, B., Sachse, G., Diskin, G., Logan, J., Worden, H., Kulawik, S., Osterman, G., Eldering, A., Herman, R., Shephard, M., 2007. TES carbon monoxide validation with DACOM aircraft measurements during INTEX-B 2006. J. Geophys. Res. 112, D24S48. doi:10.1029/2007JD008803

Millán, M., Estrela, M., Sanz, M., 2005. Climatic feedbacks and desertification: the Mediterranean model. J. ... 684-701.

Molina, L.T., Molina, M.J. (Eds.), 2002. Air Quality in the Mexico Megacity, Alliance for Global Sustainability Bookseries. Springer Netherlands, Dordrecht. doi:10.1007/978-94010-0454-1

Monks, P.S., Granier, C., Fuzzi, S., Stohl, A., Williams, M.L., Akimoto, H., Amann, M., 
682

683

684

685

686

687

688

689

690

691

692

693

694

695

696

697

698

699

700

701

702

703

704

705

706

707

708

709

710

711

712

713

714

715

716

717

718

719

Baklanov, A., Baltensperger, U., Bey, I., Blake, N., Blake, R.S., Carslaw, K., Cooper, O.R., Dentener, F., Fowler, D., Fragkou, E., Frost, G.J., Generoso, S., Ginoux, P., Grewe, V., Guenther, A., Hansson, H.C., Henne, S., Hjorth, J., Hofzumahaus, A., Huntrieser, H., Isaksen, I.S.A., Jenkin, M.E., Kaiser, J., Kanakidou, M., Klimont, Z., Kulmala, M., Laj, P., Lawrence, M.G., Lee, J.D., Liousse, C., Maione, M., McFiggans, G., Metzger, A., Mieville, A., Moussiopoulos, N., Orlando, J.J., O’Dowd, C.D., Palmer, P.I., Parrish, D.D., Petzold, A., Platt, U., Pöschl, U., Prévôt, A.S.H., Reeves, C.E., Reimann, S., Rudich, Y., Sellegri, K., Steinbrecher, R., Simpson, D., ten Brink, H., Theloke, J., van der Werf, G.R., Vautard, R., Vestreng, V., Vlachokostas, C., von Glasow, R., 2009. Atmospheric composition change - global and regional air quality. Atmos. Environ. 43, 5268-5350. doi:10.1016/j.atmosenv.2009.08.021

Müller, J.-F., Stavrakou, T., 2005. Inversion of $\mathrm{CO}$ and $\mathrm{NO}_{\mathrm{x}}$ emissions using the adjoint of the IMAGES model. Atmos. Chem. Phys. 5, 1157-1186. doi:10.5194/acp-5-1157-2005

Myriokefalitakis, S., Daskalakis, N., Mihalopoulos, N., Baker, A.R., Nenes, A., Kanakidou, M., 2015. Changes in dissolved iron deposition to the oceans driven by human activity: a 3-D global modelling study. Biogeosciences 12, 3973-3992. doi:10.5194/bg-12-3973-2015

Myriokefalitakis, S., Tsigaridis, K., Mihalopoulos, N., Sciare, J., Nenes, A., Kawamura, K., Segers, A., Kanakidou, M., 2011. In-cloud oxalate formation in the global troposphere: a 3D modeling study. Atmos. Chem. Phys. 11, 5761-5782. doi:10.5194/acp-11-5761-2011

Myriokefalitakis, S., Vignati, E., Tsigaridis, K., Papadimas, C., Sciare, J., Mihalopoulos, N., Facchini, M.C., Rinaldi, M., Dentener, F.J., Ceburnis, D., Hatzianastasiou, N., O'Dowd, C.D., van Weele, M., Kanakidou, M., 2010. Global Modeling of the Oceanic Source of Organic Aerosols. Adv. Meteorol. 2010, 1-16. doi:10.1155/2010/939171

Myriokefalitakis, S., Vrekoussis, M., Tsigaridis, K., Wittrock, F., Richter, A., Brühl, C., Volkamer, R., Burrows, J.P., Kanakidou, M., 2008. The influence of natural and anthropogenic secondary sources on the glyoxal global distribution. Atmos. Chem. Phys. Discuss. 8, 1673-1708. doi:10.5194/acpd-8-1673-2008

Naik, V., Voulgarakis, A., Fiore, A.M., Horowitz, L.W., Lamarque, J.-F., Lin, M., Prather, M.J., Young, P.J., Bergmann, D., Cameron-Smith, P.J., Cionni, I., Collins, W.J., Dalsøren, S.B., Doherty, R., Eyring, V., Faluvegi, G., Folberth, G.A., Josse, B., Lee, Y.H., MacKenzie, I.A., Nagashima, T., van Noije, T.P.C., Plummer, D.A., Righi, M., Rumbold, S.T., Skeie, R., Shindell, D.T., Stevenson, D.S., Strode, S., Sudo, K., Szopa, S., Zeng, G., 2013. Preindustrial to present-day changes in tropospheric hydroxyl radical and methane lifetime from the Atmospheric Chemistry and Climate Model Intercomparison Project (ACCMIP). Atmos. Chem. Phys. 13, 5277-5298. doi:10.5194/acp-13-5277-2013

Nassar, R., Logan, J.A., Worden, H.M., Megretskaia, I.A., Bowman, K.W., Osterman, G.B., Thompson, A.M., Tarasick, D.W., Austin, S., Claude, H., Dubey, M.K., Hocking, W.K., Johnson, B.J., Joseph, E., Merrill, J., Morris, G.A., Newchurch, M., Oltmans, S.J., Posny, F., Schmidlin, F.J., Vömel, H., Whiteman, D.N., Witte, J.C., 2008. Validation of Tropospheric Emission Spectrometer (TES) nadir ozone profiles using ozonesonde measurements. J. Geophys. Res. 113, D15S17. doi:10.1029/2007JD008819

Olivié, D.J.L., 2004. Comparison between archived and off-line diagnosed convective mass fluxes in the chemistry transport model TM3. J. Geophys. Res. 109, D11303. doi:10.1029/2003JD004036 
Parrish, D.D., Singh, H.B., Molina, L., Madronich, S., 2011. Air quality progress in North American megacities: A review. Atmos. Environ. 45, 7015-7025. doi:10.1016/j.atmosenv.2011.09.039

Pausata, F.S.R., Pozzoli, L., Vignati, E., Dentener, F.J., 2012. North Atlantic Oscillation and tropospheric ozone variability in Europe: model analysis and measurements intercomparison. Atmos. Chem. Phys. 12, 6357-6376. doi:10.5194/acp-12-6357-2012

Poisson, N., Kanakidou, M., Crutzen, P., 2000. Impact of Non-Methane Hydrocarbons on Tropospheric Chemistry and the Oxidizing Power of the Global Troposphere: 3Dimensional Modelling Results. J. Atmos. Chem. 36, 157-230. doi:10.1023/A:1006300616544

Quennehen, B., Raut, J.-C., Law, K.S., Ancellet, G., Clerbaux, C., Kim, S.-W., Lund, M.T., Myhre, G., Olivié, D.J.L., Safieddine, S., Skeie, R.B., Thomas, J.L., Tsyro, S., Bazureau, A., Bellouin, N., Daskalakis, N., Hu, M., Kanakidou, M., Klimont, Z., Kupiainen, K., Myriokefalitakis, S., Quaas, J., Rumbold, S.T., Schulz, M., Cherian, R., Shimizu, A., Wang, J., Yoon, S.-C., Zhu, T., 2015. Multi-model evaluation of short-lived pollutant distributions over East Asia during summer 2008. Atmos. Chem. Phys. Discuss. 15, 11049-11109. doi:10.5194/acpd-15-11049-2015

Russell, G.L., Lerner, J.A., 1981. A New Finite-Differencing Scheme for the Tracer Transport Equation. J. Appl. Meteorol. 20, 1483-1498. doi:10.1175/15200450(1981)020<1483:ANFDSF $>2.0 . \mathrm{CO} ; 2$

Sciare, J., Oikonomou, K., Favez, O., Liakakou, E., Markaki, Z., Cachier, H., Mihalopoulos, N., 2008. Long-term measurements of carbonaceous aerosols in the Eastern Mediterranean: evidence of long-range transport of biomass burning. Atmos. Chem. Phys. 8, 5551-5563. doi:10.5194/acp-8-5551-2008

Stevenson, D.S., Dentener, F.J., Schultz, M.G., Ellingsen, K., van Noije, T.P.C., Wild, O., Zeng, G., Amann, M., Atherton, C.S., Bell, N., Bergmann, D.J., Bey, I., Butler, T., Cofala, J., Collins, W.J., Derwent, R.G., Doherty, R.M., Drevet, J., Eskes, H.J., Fiore, a. M., Gauss, M., Hauglustaine, D. a., Horowitz, L.W., Isaksen, I.S. a., Krol, M.C., Lamarque, J.-F.F., Lawrence, M.G., Montanaro, V., Müller, J.-F.F., Pitari, G., Prather, M.J., Pyle, J. a., Rast, S., Rodriguez, J.M., Sanderson, M.G., Savage, N.H., Shindell, D.T., Strahan, S.E., Sudo, K., Szopa, S., 2006. Multimodel ensemble simulations of present-day and near-future tropospheric ozone. J. Geophys. Res. 111, D08301. doi:10.1029/2005jd006338

Stohl, A., Aamaas, B., Amann, M., Baker, L.H., Bellouin, N., Berntsen, T.K., Boucher, O., Cherian, R., Collins, W., Daskalakis, N., Dusinska, M., Eckhardt, S., Fuglestvedt, J.S., Harju, M., Heyes, C., Hodnebrog, Ø., Hao, J., Im, U., Kanakidou, M., Klimont, Z., Kupiainen, K., Law, K.S., Lund, M.T., Maas, R., MacIntosh, C.R., Myhre, G., Myriokefalitakis, S., Olivié, D., Quaas, J., Quennehen, B., Raut, J.-C., Rumbold, S.T., Samset, B.H., Schulz, M., Seland, Ø., Shine, K.P., Skeie, R.B., Wang, S., Yttri, K.E., Zhu, T., 2015. Evaluating the climate and air quality impacts of short-lived pollutants. Atmos. Chem. Phys. Discuss. 15, 15155-15241. doi:doi:10.5194/acpd-15-15155-2015

Tiedtke, M., 1989. A Comprehensive Mass Flux Scheme for Cumulus Parameterization in Large-Scale Models. Mon. Weather Rev. 117, 1779-1800. doi:10.1175/15200493(1989)117<1779:ACMFSF $>2.0 . C O ; 2$

van der A, R.J., Allaart, M. a. F., Eskes, H.J., 2010. Multi sensor reanalysis of total ozone. 
van Noije, T.P.C., Eskes, H.J., van Weele, M., van Velthoven, P.F.J., 2004. Implications of the enhanced Brewer-Dobson circulation in European Centre for Medium-Range Weather Forecasts reanalysis ERA-40 for the stratosphere-troposphere exchange of ozone in global chemistry transport models. J. Geophys. Res. 109, D19308. doi:10.1029/2004JD004586

Voulgarakis, A., Naik, V., Lamarque, J.-F., Shindell, D.T., Young, P.J., Prather, M.J., Wild, O., Field, R.D., Bergmann, D., Cameron-Smith, P., Cionni, I., Collins, W.J., Dalsøren, S.B., Doherty, R.M., Eyring, V., Faluvegi, G., Folberth, G.A., Horowitz, L.W., Josse, B., MacKenzie, I.A., Nagashima, T., Plummer, D.A., Righi, M., Rumbold, S.T., Stevenson, D.S., Strode, S. a., Sudo, K., Szopa, S., Zeng, G., 2013. Analysis of present day and future $\mathrm{OH}$ and methane lifetime in the ACCMIP simulations. Atmos. Chem. Phys. 13, 2563-2587. doi:10.5194/acp-13-2563-2013

Voulgarakis, A., Telford, P.J., Aghedo, a. M., Braesicke, P., Faluvegi, G., Abraham, N.L., Bowman, K.W., Pyle, J. a., Shindell, D.T., 2011. Global multi-year O3-CO correlation patterns from models and TES satellite observations. Atmos. Chem. Phys. 11, 5819-5838. doi:10.5194/acp-11-5819-2011

Yue, X., Unger, N., 2014. Ozone vegetation damage effects on gross primary productivity in the United States. Atmos. Chem. Phys. 14, 9137-9153. doi:10.5194/acp-14-9137-2014

Zanis, P., Hadjinicolaou, P., Pozzer, A., Tyrlis, E., Dafka, S., Mihalopoulos, N., Lelieveld, J., 2014. Summertime free-tropospheric ozone pool over the eastern Mediterranean/Middle East. Atmos. Chem. Phys. 14, 115-132. doi:10.5194/acp-14-115-2014

785

786 
787 Table 1. Outline of simulations performed for this study.

\begin{tabular}{|c|c|}
\hline Simulation & Description \\
\hline BASE & The base case simulation for the year 2008 . \\
\hline MaskANTRC & Neglecting the anthropogenic emissions in the Eastern Mediterranean domain. \\
\hline MaskBB & Neglecting the biomass burning emissions in the Eastern Mediterranean domain. \\
\hline MaskBIO & Neglecting the biogenic emissions in the Eastern Mediterranean domain. \\
\hline MaskALL & Neglecting the anthropogenic, biomass burning and biogenic emissions in the \\
\hline MaskEU & Neglecting all emissions over Europe. \\
\hline MaskNAM & Neglecting all emissions over Northern America. \\
\hline MaskAS & Neglecting all emissions over Asia. \\
\hline MaskAF & Neglecting all emissions over Africa. \\
\hline FUTURE & Taking into account projected anthropogenic emission of the year 2050 . \\
\hline
\end{tabular}



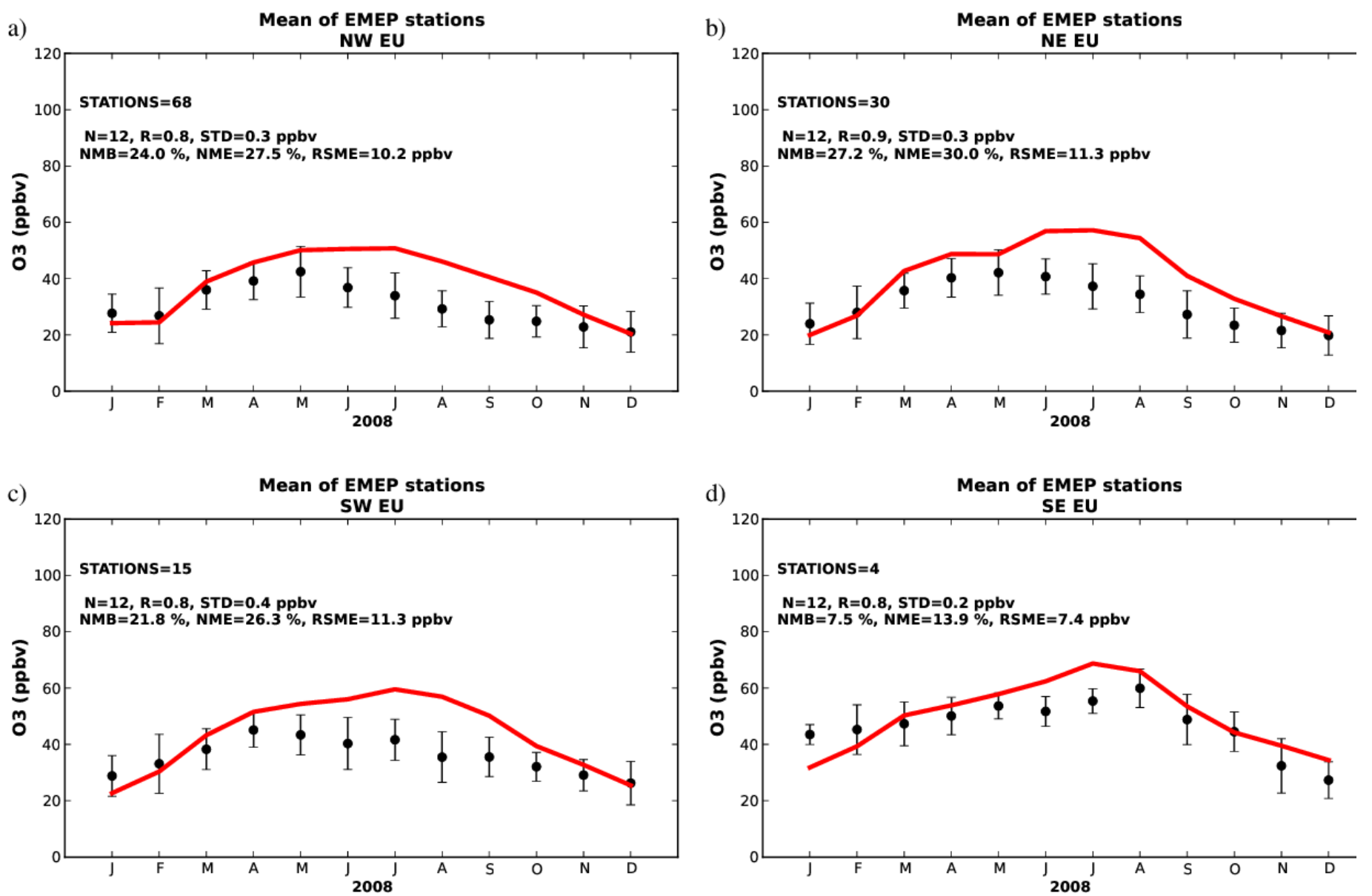

Fig. 1. Comparison of $\mathrm{O}_{3}$ levels $\left(\mathrm{ppb}_{\mathrm{v}}\right)$ from TM4-ECPL BASE simulation (red lines) with surface monthly mean observations from EMEP stations (black dots) and the respective standard deviation of the observed $\mathrm{O}_{3}$ levels $\left(\mathrm{ppb}_{\mathrm{v}}\right.$ ) (with black vertical lines) at a) NW Europe, b) NE Europe, c) SW Europe and d) SE Europe. 

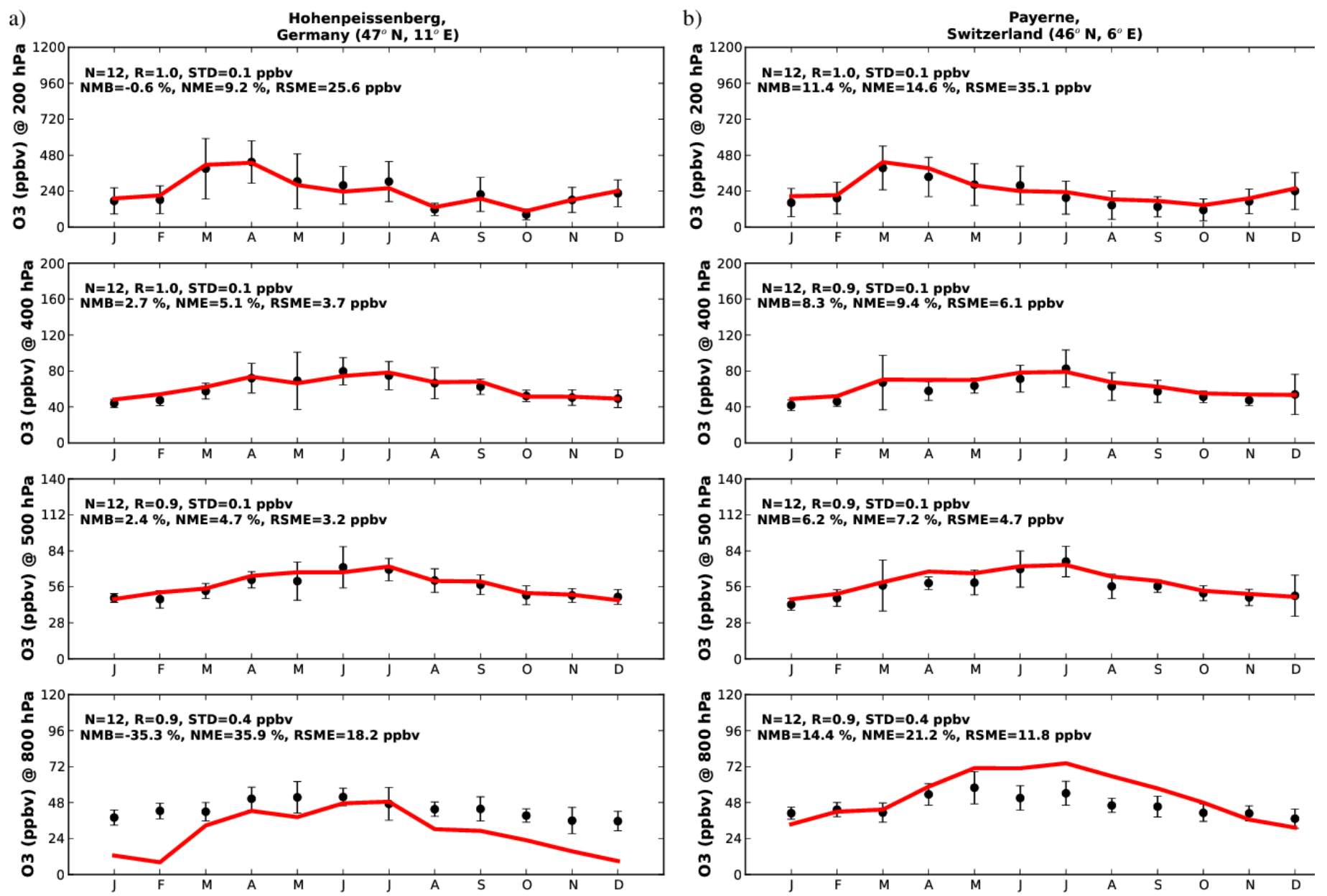

796

797

798

799

800

801

802
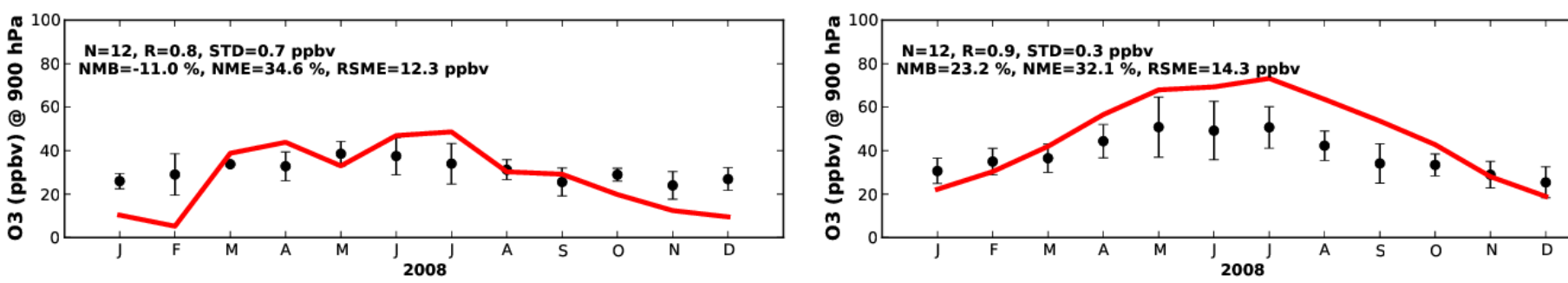

Fig. 2. Comparison of $\mathrm{O}_{3}$ levels $\left(\mathrm{ppb}_{\mathrm{v}}\right)$ from TM4-ECPL BASE simulation (red line) with $\mathrm{O}_{3}$ sonde station data (black dots, mean and standard deviation) at five pressure levels (900; 800; 500; 400; $200 \mathrm{hPa}$ ) for two WOUDC stations: a) Hohenpeissenberg, Germany $\left(47^{\circ} \mathrm{N}, 11 \mathrm{E}^{\mathrm{o}}\right)$; b) Payerne, Switzerland $\left(46^{\circ} \mathrm{N}, 6^{\circ} \mathrm{E}\right.$ ) (see additional comparisons at other European stations in Fig. $\mathrm{S} 3$ in the supplementary material). 
a)

O3, TM4-ECPL,

$800-400 \mathrm{hPa}$

Annual Mean, 2008

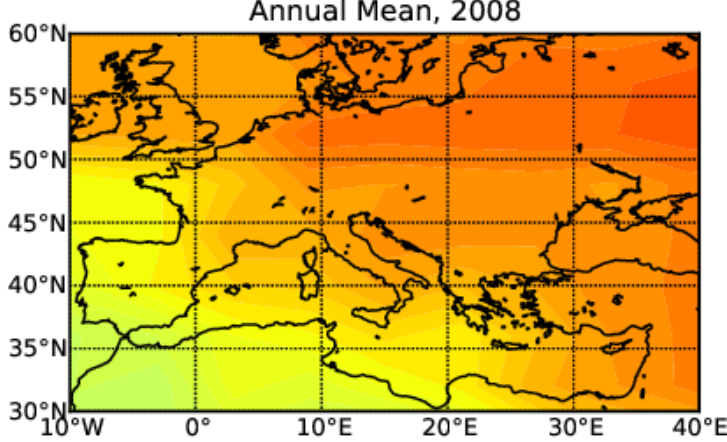

b)

CO, TM4-ECPL,

$800-400 \mathrm{hPa}$

Annual Mean, 2008

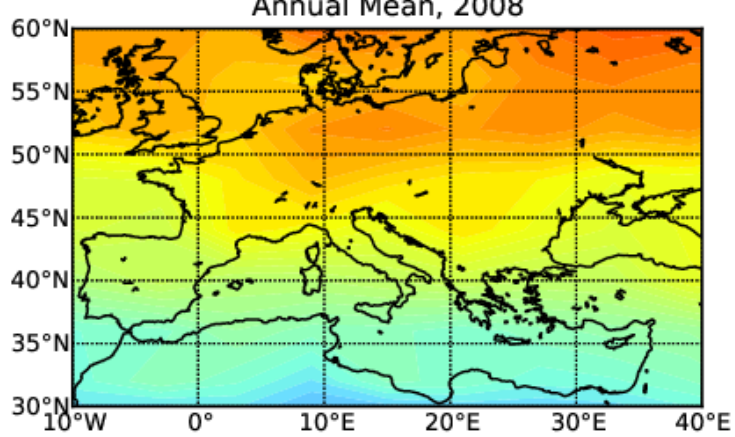

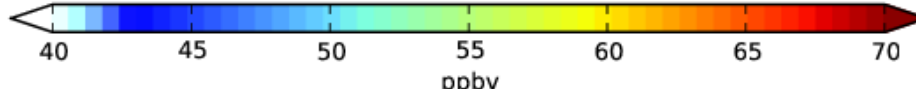

c)

O3, \%(TM4-ECPL - TES)/TES,
$800-400 \mathrm{hPa}$ Annual Mean 2008

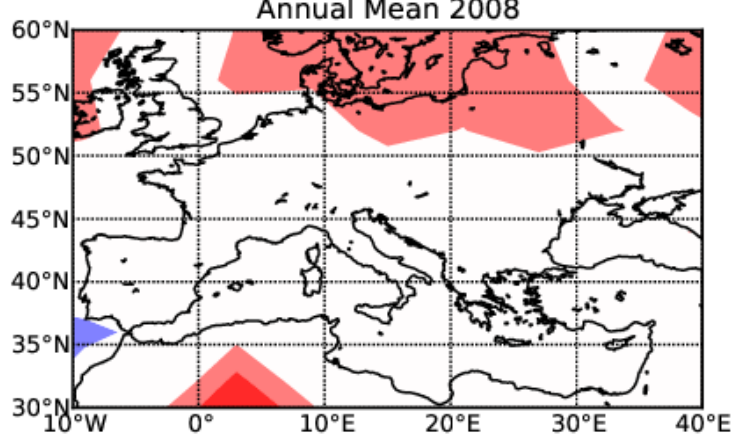

d)

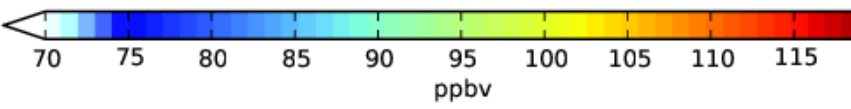

CO, \%(TM4-ECPL - TES)/TES,

$800-400 \mathrm{hPa}$

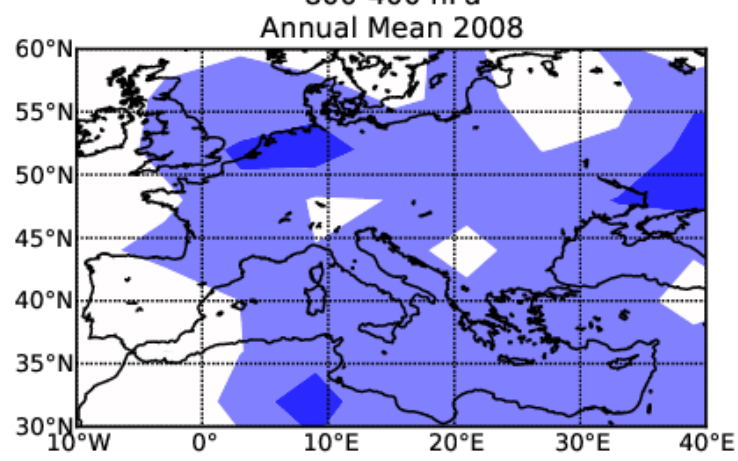

803

804

805

806

807

808
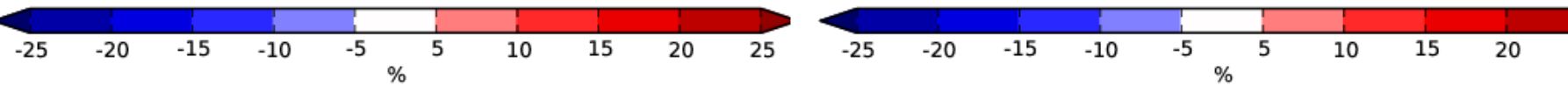

Fig. 3. Simulated annual mean free tropospheric concentrations $\left(\mathrm{ppb}_{\mathrm{v}}\right)$ in the $800-400 \mathrm{hPa}$ zone over Europe for a) $\mathrm{O}_{3}$, b) $\mathrm{CO}$, and the percentage difference of TM4-ECPL BASE simulation results from TES retrieved concentrations [100 x (BASE-TES)/TES] for c) $\mathrm{O}_{3}$ and d) $\mathrm{CO}$ in the same zone. 

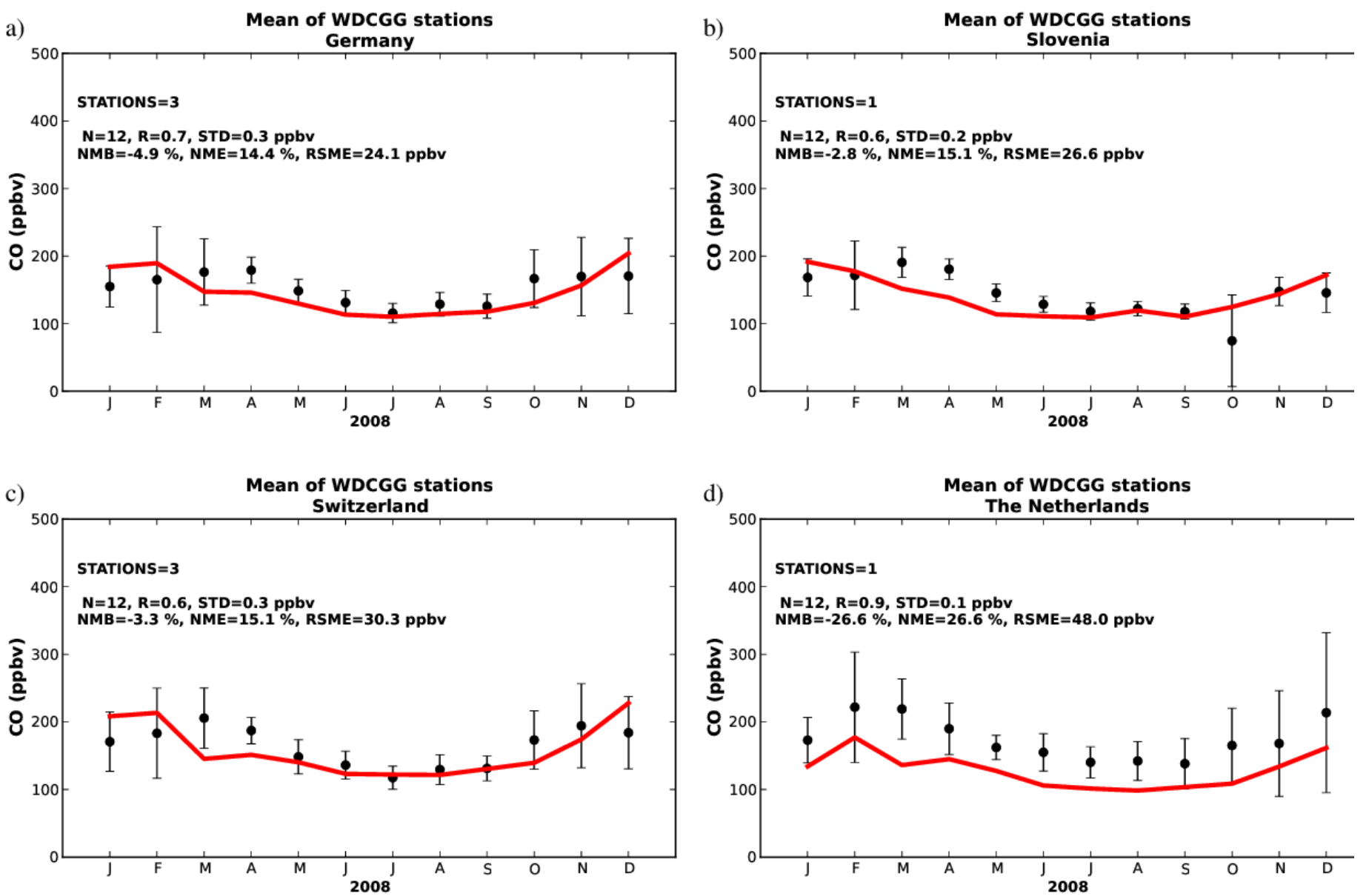

810 Fig. 4. Comparison of surface CO levels $\left(\mathrm{ppb}_{\mathrm{v}}\right)$ calculated by TM4-ECPL BASE simulation (red 811 line) with observations (monthly mean values for WDCGG stations, black dots, mean and 812 standard deviation) at a) Germany, b) Slovenia c) Switzerland and d) The Netherlands 
814

815 Fig. 5. $\mathrm{O}_{3}$ annual (2008; BASE simulation) budget analysis for Western (a,c; shaded area) and

816 Eastern Mediterranean (b,d; non-shaded area) for $a, b)$ the free troposphere (FT; upper figure) and

$817 \mathrm{c}, \mathrm{d}$ ) the boundary layer (BL; bottom figure) including the burden, the chemistry, the deposition

818 and the fluxes at each boundary. All budget terms and fluxes $\left(\mathrm{Tg} \mathrm{yr}^{-1}\right)$ are annual totals; burdens

819 (Tg) are annual averages. Straight arrows indicate N-S and W-E advection fluxes, while curved

820

821 arrows indicate vertical fluxes from the upper troposphere to the FT and from the FT to the BL. a)

c) 
822

823

824

825

826

827

828

829

830

831 a)

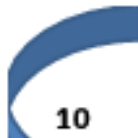

c)

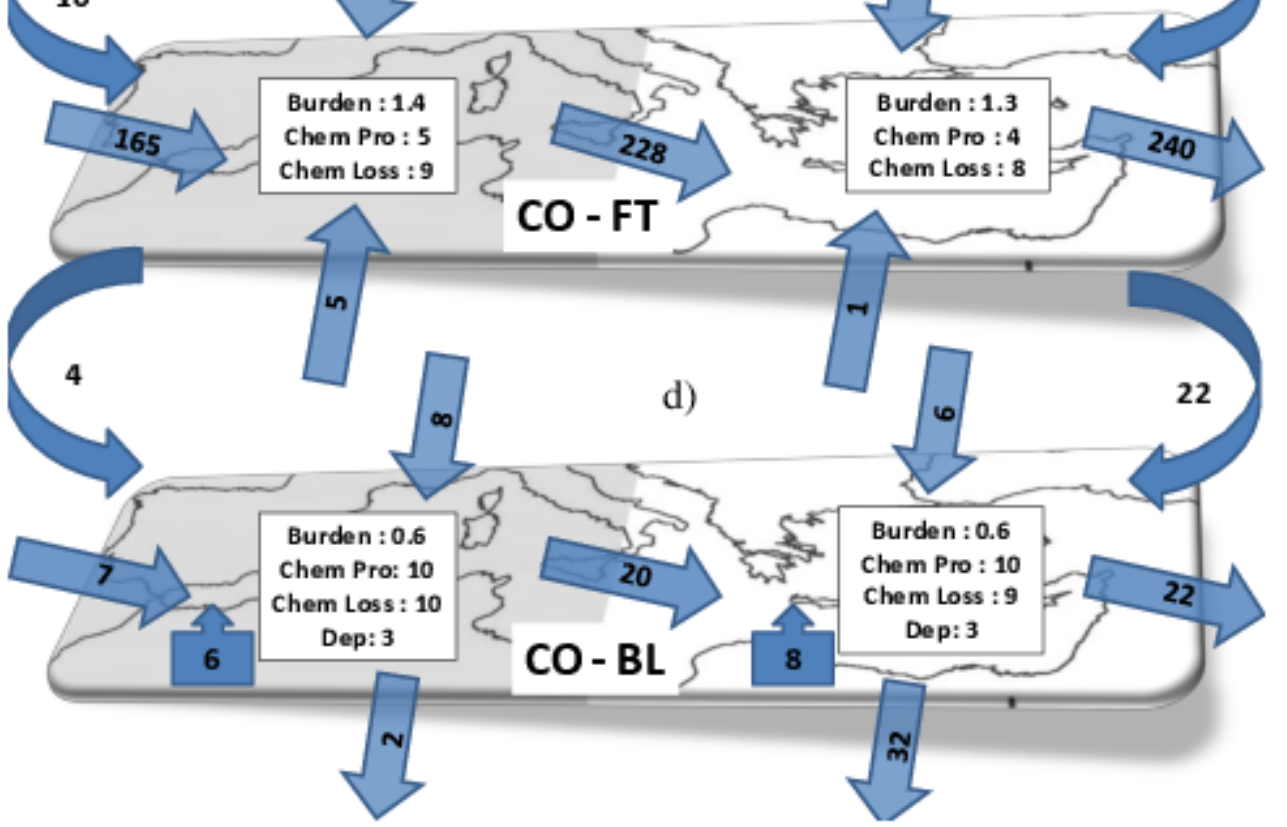

Fig. 6. CO annual (2008; BASE simulation) budget analysis for Western (a,c; shaded area) and Eastern Mediterranean (b,d; non-shaded area) for a,b) the free troposphere (FT; upper figure) and $\mathrm{c}, \mathrm{d}$ ) the boundary layer (BL; bottom figure) including the burden, the emissions, the chemistry, the deposition and the fluxes at each boundary.. Straight arrows indicate N-S and W-E advection fluxes, curved arrows indicate vertical fluxes from the upper troposphere to the FT and from the FT to the BL and box-arrows indicate $\mathrm{CO}$ emissions. 
a)

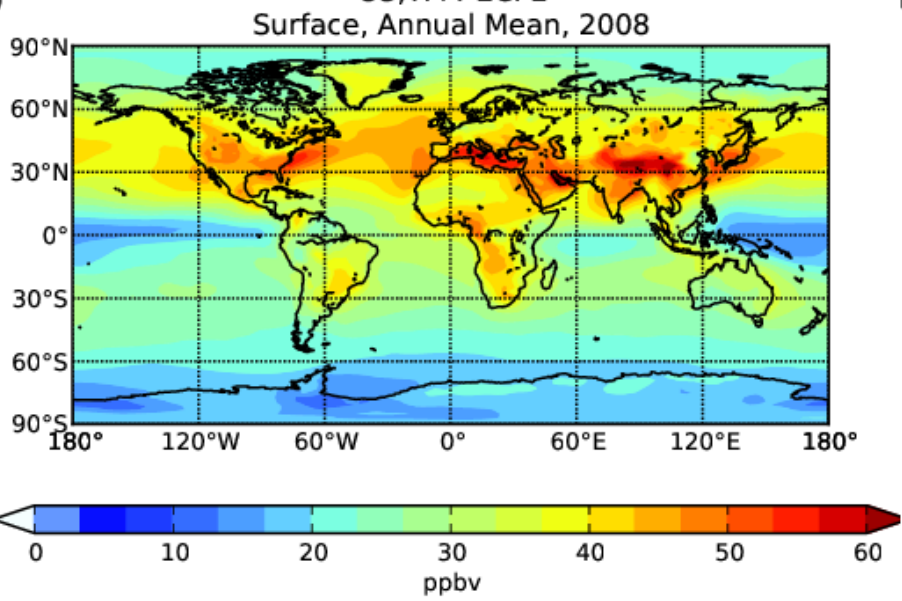

c)

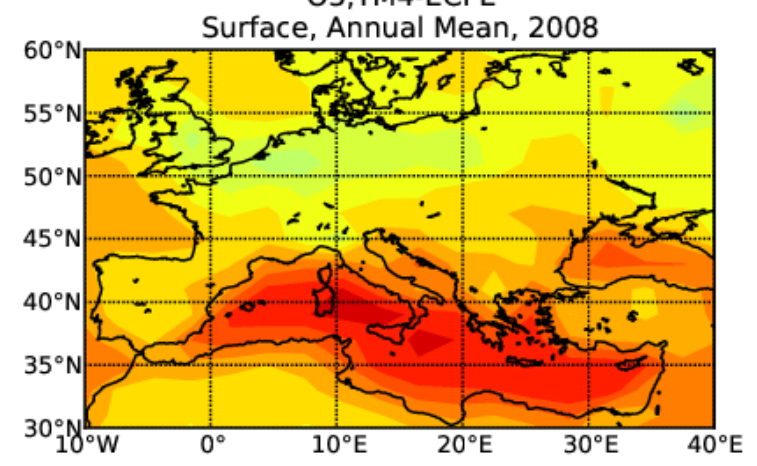

b)

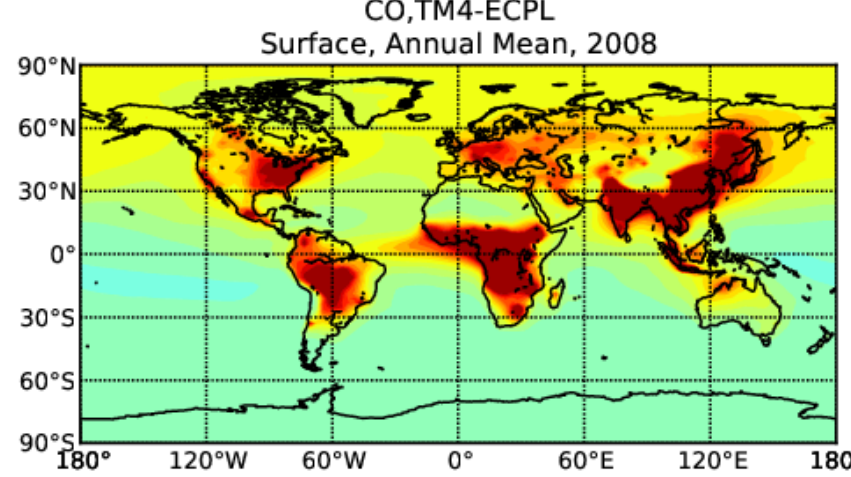

d)
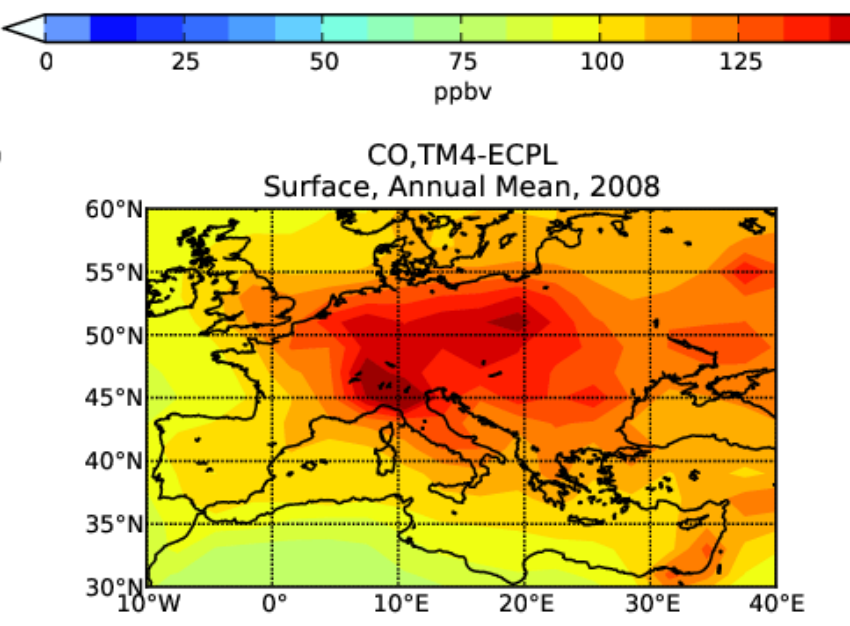

832

833

834

835
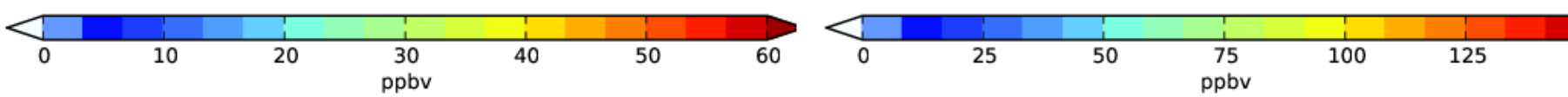

Fig. 7. Simulated $a, c) \mathrm{O}_{3}$ and $\left.b, d\right) C O$ surface concentrations $\left(p p b_{v}\right)$ for TM4-ECPL BASE simulation for the globe $(a, b)$ and focus on the Mediterranean area $(c, d)$. 
a)

O3, TM4-ECPL,

\%MaskANTHRO Contribution,
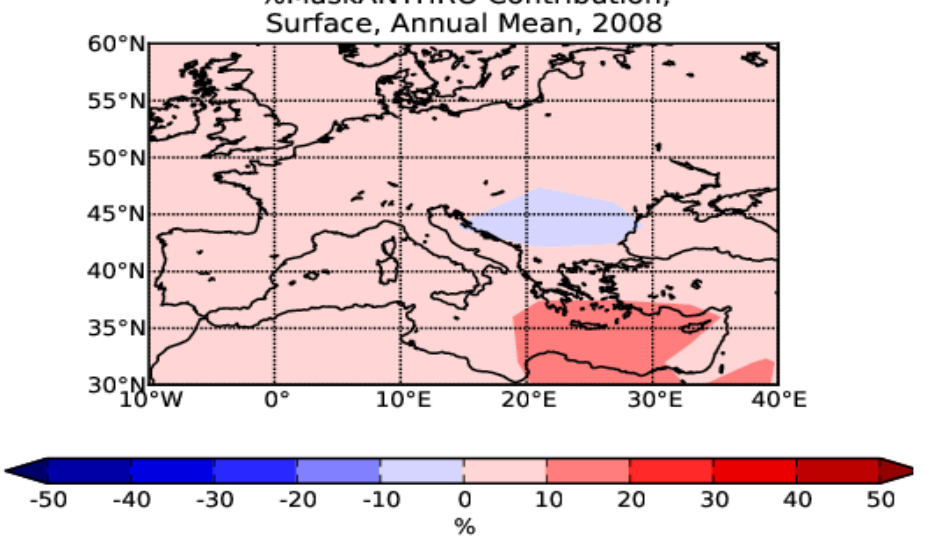

c)

O3, TM4-ECPL,

\%MaskALL Contribution, Surface, Annual Mean, 2008

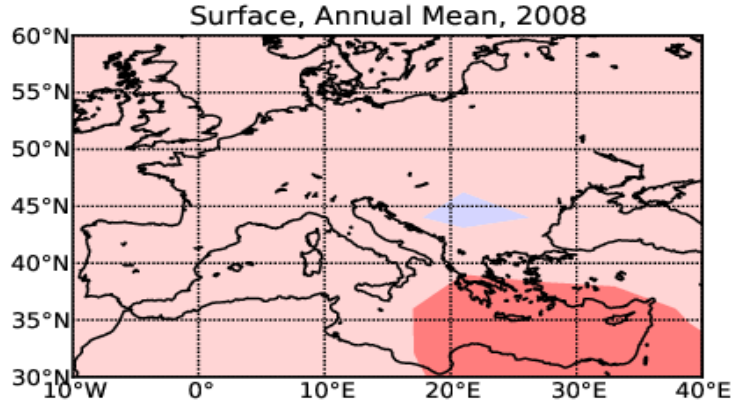

b)

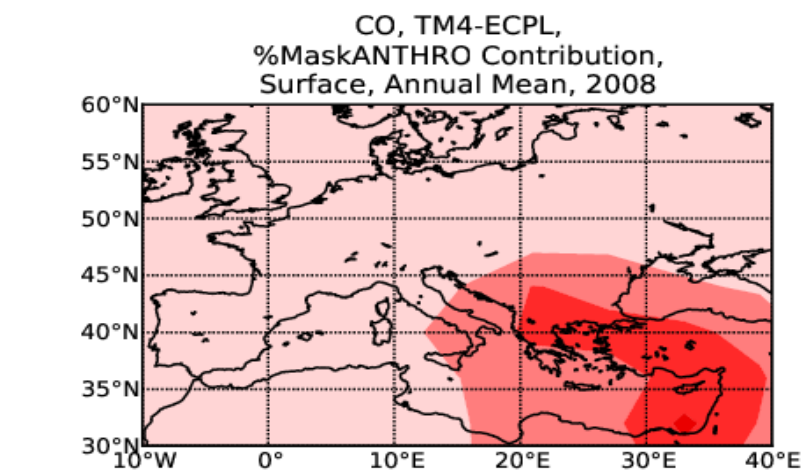

d)

CO, TM4-ECPL,

\%MaskALL Contribution,
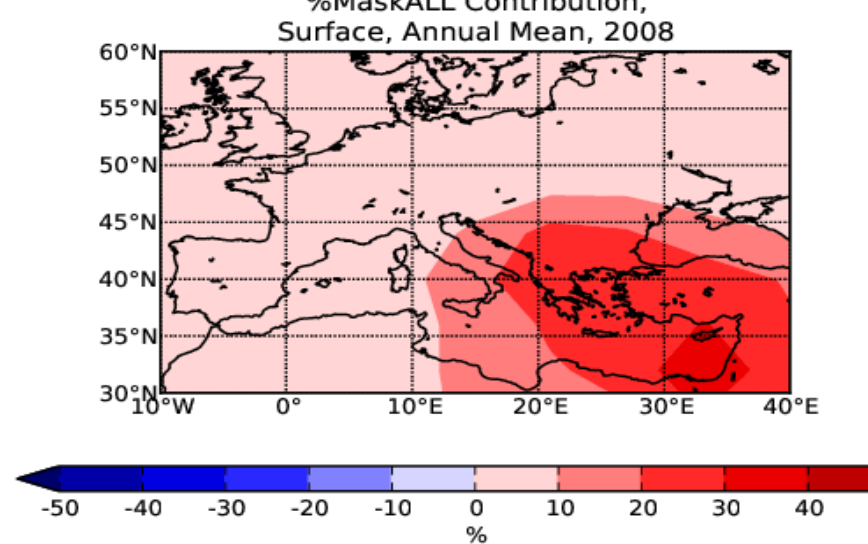

e)

O3, TM4-ECPL,

\%FUTURE Contribution,

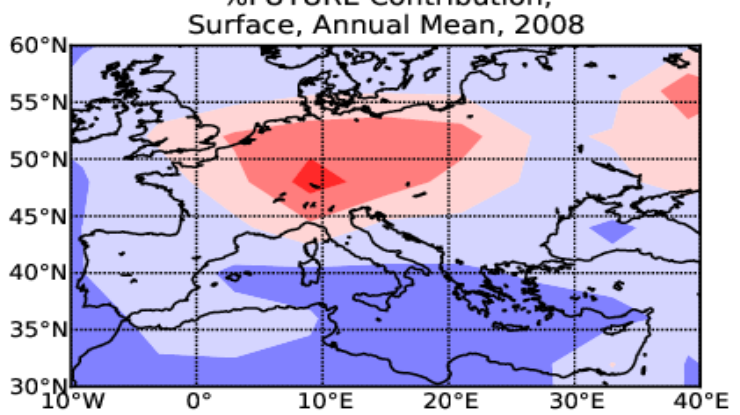

f)

CO, TM4-ECPL, \%FUTURE Contribution,

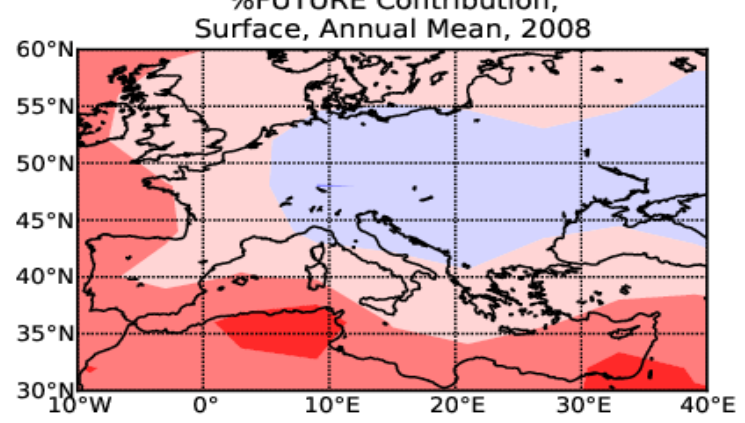

837

838

839

840

841

842

843

844
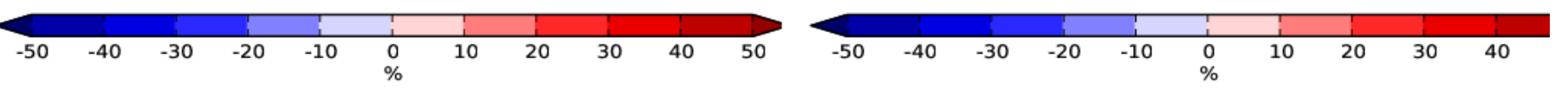

Fig. 8. Simulated relative contribution (\%) to $\mathrm{O}_{3}$ (left panels) and $\mathrm{CO}$ (right panels) surface concentrations of $\mathrm{a}, \mathrm{b})$ Anthropogenic emissions over EM (MaskANTHRO); c,d) All emissions over the EM (MaskALL); and e,f) Future anthropogenic emissions (FUTURE), compared to the TM4-ECPL BASE simulation (figures a) through d) are computed as [100*(BASEMaskX)/BASE]; where MaskX is the respective sensitivity simulation, while e) and f) are computed as [100x(FUTURE-BASE)/BASE]). 